\title{
Ecotoxicological assessment of the anticancer drug cisplatin in the polychaete Nereis diversicolor
}

\author{
T.G. Fonseca a,b ${ }^{\text {, M.B. Morais }}{ }^{\text {a }}$, T. Rocha a , D.M.S. Abessa ${ }^{\text {b }}$, M. Aureliano ${ }^{\text {c }}$, M.J. Bebianno ${ }^{\text {a,* }}$ \\ a CIMA, Centre for Marine and Environmental Research, University of Algarve, Campus Gambelas, 8005-135 Faro, Portugal

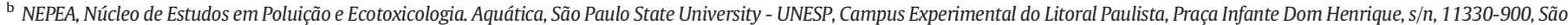 \\ Vicente, SP, Brazil

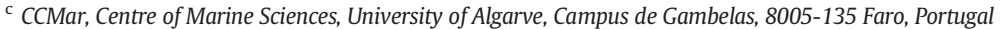

\section{H I G H L I G H T S}

- Polychaetes Nereis diversicolor were exposed for 14 days to cisplatin (CisPt) anticancer drug.

- CisPt induced behavioural impairments and neurotoxicity in $N$. diversicolor

- Oxidative stress and lipid peroxidation were observed after cytotoxic exposure.

- DNA damage were not detected in coelomocytes of polychaetes exposed to CisPt.
G R A P H I C A L A B S T R A C T

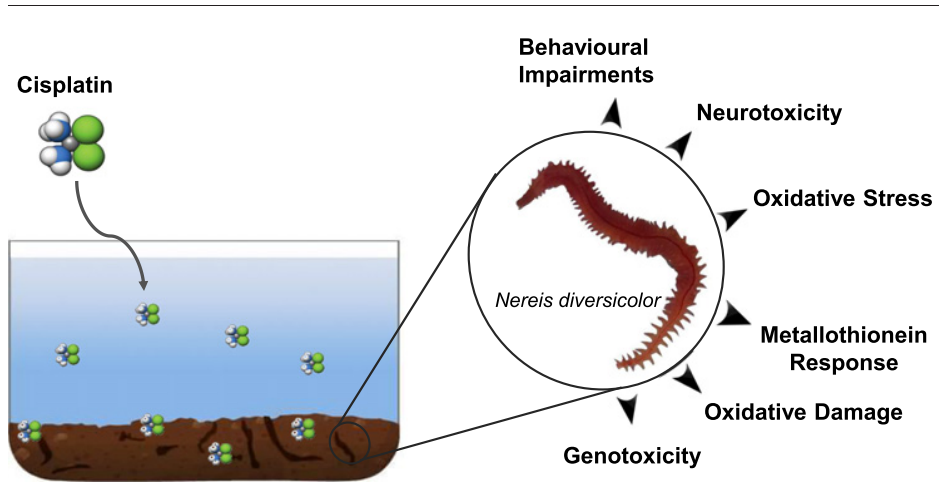

A B S T R A C T

Anticancer drugs are designed to inhibit tumor cell proliferation by interacting with DNA and altering cellular growth factors. When released into the waterbodies of municipal and hospital effluents these pharmaceutical compounds may pose a risk to non-target aquatic organisms, due to their mode of action (cytotoxic, genotoxic, mutagenic and teratogenic). The present study aimed to assess the ecotoxicological potential of the alkylating agent cisplatin (CisPt) to the polychaete Nereis diversicolor, at a range of relevant environmental concentrations (i.e. $0.1,10$ and $100 \mathrm{ng} \mathrm{Pt} \mathrm{L}^{-1}$ ). Behavioural impairment (burrowing kinetic impairment), ion pump effects (SR $\mathrm{Ca}^{2+}$-ATPase), neurotoxicity (AChE activity), oxidative stress (SOD, CAT and GPXs activities), metal exposure (metallothionein-like proteins - MTLP), biotransformation (GST), oxidative damage (LPO) and genotoxicity (DNA damage), were selected as endpoints to evaluate the sublethal responses of the ragworms after 14-days of exposure in a water-sediment system. Significant burrowing impairment occurred in worms exposed to the highest CisPt concentration (100 ng Pt $\mathrm{L}^{-1}$ ) along with neurotoxic effects. The activity of antioxidant enzymes (SOD, CAT) and second phase biotransformation enzyme (GST) was inhibited but such effects were compensated by MTLP induction. Furthermore, LPO levels also increased. Results showed that the mode of action of cisplatin may pose a risk to this aquatic species even at the range of $n g \mathrm{~L}^{-1}$.

\footnotetext{
* Corresponding author.

E-mail address: mbebian@ualg.pt (M.J. Bebianno).
} 


\section{Introduction}

The increase of global cancer incidence in the human population led to an increase of development, prescription and combination of drugs, with cytotoxic and cytostatic modes of action (Suspiro and Prista, 2011). They were designed to inhibit cell replication and transcription through direct or indirect interaction with DNA and induce mutagenic, cytotoxic, genotoxic and carcinogenic effects (Johnson et al., 2008; Besse et al., 2012; Parrella et al., 2014).

Excretion of chemotherapeutic drugs, unchanged or metabolized by patients, is considered the primary source by which these pharmaceuticals enter the waterbodies, via municipal and/or hospital effluents (Johnson et al., 2008; Liu et al., 2010; Booker et al., 2014).Therefore, concern is now emerging about their fate in aquatic systems and long-term exposure to organisms at environmentally relevant concentrations.

Among the cytotoxic drugs used in chemotherapy, platinum-based drugs (i.e. cisplatin; carboplatin; oxaliplatin) comprise the class L01XA of the anatomical therapeutic chemicals (ATC) which are used individually or in combination to treat various tumours, such as ovarian, testicular, bladder and lung cancers (Deans and West, 2011; Parrella et al., 2014).

Cisplatin (CisPt), or cis-diammine-dichloroplatinum II, was approved for clinical uses in 1978 and is considered one of the most promising and widely used platinum-based therapeutic anti-cancer drugs (Arnesano and Natile, 2009; Gómez-Ruiz et al., 2012). Within 24 h of intravenous infusion (i.e. $50-100 \mathrm{mg} \mathrm{m}^{2}$ body surface), patients excrete $28 \pm 4 \%$ of platinum complexes via urine (Vermorken et al., 1986; Dwyer et al., 2000), 40\% in the form of monoaquacisplatin (Hann et al., 2003). In aqueous solutions of low chloride levels (i.e. intracellular fluids), CisPt chloro ligands are gradually hydrolysed according to the ionic strength of receiving waters in a stepwise process to generate cis$\left[\mathrm{PtCl}\left(\mathrm{H}_{2} \mathrm{O}\right)\left(\mathrm{NH}_{3}\right)_{2}\right]^{+}$(monoaquacisplatin) and cis- $\left[\mathrm{PtCl}\left(\mathrm{H}_{2} \mathrm{O}\right)\left(\mathrm{NH}_{3}\right)_{2}\right]^{+}$ (diaquacisplatin), the former being associated with antitumor activity and toxicity (Hann et al., 2003; Lenz et al., 2005; Curtis et al., 2010). $>75 \%$ of CisPt enters sewage treatment plants and surface waters as the reactive monoaquacisplatin (Hann et al., 2003), with a propensity to interact with biotic and abiotic matrix (Curtis et al., 2010; Vyas et al., 2014).

The contribution of platinum (Pt) from Pt-based drugs to the environment is smaller compared to other Pt sources such as car catalytic converters (Lenz et al., 2007a; Curtis et al., 2010). Pt from chemotherapeutic drugs was detected in sewage treatment plants influents (1 ng $\mathrm{L}^{-1}$ to $250 \mu \mathrm{g} \mathrm{L}{ }^{-1}$ ) and effluents (i.e. $2 \mu \mathrm{g} \mathrm{L} \mathrm{L}^{-1}$ to $150 \mu \mathrm{g} \mathrm{L}^{-1}$ ), from hospitals ( $<10$ to $145 \mu \mathrm{g} \mathrm{L}^{-1}$ ) and surface waters ( 0.01 to $0.54 \mathrm{ng} \mathrm{L}^{-1}$ ) (Steger-Hartmann et al., 1997; Kümmerer et al., 1999; Lenz et al., 2005, 2007b; Vyas et al., 2014) but in the form of CisPt was only detected in hospital effluents (1.7 ng Pt L ${ }^{-1}$ ) (Hann et al., 2005) and surface waters (0.0028 to $0.0125 \mathrm{ng} \mathrm{Pt} \mathrm{L}^{-1}$ ) (Vyas et al., 2014) (Table 1). However, the behaviour and fate of CisPt in the marine environment remains unclear (Turner and Mascorda, 2015). Although pharmaceuticals are mainly hydrophilic and tend to be present in the dissolved form of the water column, the highly soluble CisPt molecule ( $\log$ Kow $=-2.19$ ) has a high potential to be adsorbed to suspended solids and sewage sludge (Lenz et al., 2005, 2007a, 2007b). The interaction with the solid fraction induces the formation of complexes with organic matter and partitions with the sediments (Moreno-González et al., 2015), where CisPt settles. Sediments can then act as a reservoir of these compounds and provide their continual remobilization to the water column via resuspension or trophic transfer (Buruaem et al., 2012; Araujo et al., 2013; Rodrigues et al., 2013).

Environmentally relevant concentrations of CisPt in aquatic sediments is unknown. Only Pt levels were detected in coastal and estuarine waters, ranging from 0.02 to $25 \mathrm{ng} \mathrm{g}^{-1}$ (Tuit and Ravizza, 2000; De Boni et al., 2007; Prichard et al., 2008; Pratt and Lottermoser, 2007; Cobelo-García et al., 2011). However, CisPt adsorption to sediments decrease from river to estuarine waters which is consistent with the reduction of reactivity of the CisPt degradation (Curtis et al., 2010; Turner and Mascorda, 2015) and indicates that dispersal of CisPt is favored towards the marine environments, where physico-chemical conditions inhibit the hydroxo species formation (Turner and Mascorda, 2015).

Although the mode of action (MoA) and uptake of CisPt to aquatic organisms remains poorly understood, the uptake in cancer cells occurs by passive diffusion or via copper transporter proteins, such as copper transporter 1 (CTR 1) (Holzer et al., 2006). CisPt reactive products are highly electrophilic and act towards nucleophilic sites in genomic and mitochondrial DNA, producing DNA inter- and intra-strand adducts that result in DNA distortion, inhibition of DNA replication and interruption of cell division (Gonzalez et al., 2001; Fuertes et al., 2003; Dasari and Bernard Tchounwou, 2014). Furthermore, CisPt has DNA-unrelated effects and can bind to nitrogen and sulfur nucleophilic sites of proteins, phospholipid membranes and cytoskeleton, while enzyme activities, receptor and protein functions are highly affected, with consequent metabolic impairment that can lead to cellular apoptosis or necrosis (Gonzalez et al., 2001; Fuertes et al., 2003; Dasari and Bernard Tchounwou, 2014; Gatti et al., 2015). The resistance to counteract CisPt activity is mainly due to the reduction of CisPt accumulation in cells; the increase of DNA repair; Pt inactivation through conjugation with glutathione; and binding to metallothioneins (Arnesano and Natile, 2009; Tadini-Buoninsegni et al., 2014).

The ecotoxicological impact of CisPt in aquatic organisms is scarce and was mainly reported for freshwater species, such as protozoans (Tetrahymena pyriformis), rotifers (Brachionus calyciflorus), microalgae (Pseudokirchneriella subcapitata), crustaceans (Daphnia magna; Ceriodaphnia dubia) and fish (Danio rerio), which showed effects on growth and reproduction inhibition (Bonnet et al., 2003; Zounková et al., 2007; Brezovsek et al., 2014), acute immobilization (Zounková et al., 2007), embryotoxicity (Kovacs et al., 2015), cytotoxicity (Gajski et al., 2015) and mortality (Parrella et al., 2014; Kovacs et al., 2015). 'CisPt' causes genotoxic effects in aquatic organisms, such as the

Table 1

Concentrations of total Pt from Pt-based anticancer drugs (e.g. cisplatin; carboplatin; oxaliplatin) and Pt detected from cisplatin drug (ng $\mathrm{L}^{-1}$ ), in aquatic compartments.

\begin{tabular}{|c|c|c|c|c|c|c|c|}
\hline \multicolumn{2}{|c|}{ Hospital effluent } & \multicolumn{2}{|c|}{ Wastewater Treatment Plants (WWTPs) } & \multicolumn{2}{|c|}{ Surface water } & \multirow[t]{2}{*}{ Detection method } & \multirow[t]{2}{*}{ Reference } \\
\hline Total Pt & Pt CisPt & WWTPs influent (Total Pt) & WWTPs effluent (Total Pt) & Total Pt & Pt CisPt & & \\
\hline- & - & $3000-250,000(a)$ & $2000-150,000(a)$ & - & - & ICP-MS; HPLC-ICP-MS & Lenz et al. (2007a, 2007b) \\
\hline $4700-145,000$ & - & - & - & & - & ICP-MS & Lenz et al. (2005) \\
\hline $30-84,590$ & - & & & $0.01-0.540$ & $0.0028-0.0125(b)$ & ICP-MS & Vyas et al. (2014) \\
\hline$<10-601$ & - & & & & & Adsorptive voltammetry & Kümmerer et al. (1999) \\
\hline $38.2-110.6$ & - & $38.2-110.6$ & - & - & - & Adsorptive voltammetry & Steger-Hartmann et al. (1997) \\
\hline- & $1,7(a)$ & - & - & & - & HPLC-ICP/MS & Hann et al. (2005) \\
\hline
\end{tabular}

(a) 24-h composite samples.

(b) Estimated concentration according to effluent rate discharge. 
induction of DNA strand breaks as observed in the microcrustaceans Daphnia magna and Ceriodaphnia dubia after $24 \mathrm{~h}$ of exposure (10 ng and $300 \mathrm{ng} \mathrm{Pt} \mathrm{L}^{-1}$, respectively) (Parrella et al., 2015), and in the marine mussel Mytillus galloprovinciallis after exposure to $100 \mathrm{ng} \mathrm{Pt} \mathrm{L}^{-1}$ (Trombini et al., 2016).

Benthic and epibenthic species accumulate contaminants by dermal contact and dietary strategies, such as filtration of suspended solids and/ or intake of sediment particles and fractions associated to organic matter (Simpson et al., 2005), but little is known about the fate of pharmaceuticals in these species. The polychaete Nereis (Hediste) diversicolor is a deposit feeder that also scavenges for organic matter and detritus on the sediments surface where it plays a relevant ecological role due to bioturbation, particle mixing and irrigation of benthic galleries (Solé et al., 2009). Therefore, $N$. diversicolor was considered a suitable model for biomonitoring purposes and application in ecotoxicology assays with emergent contaminants (Cong et al., 2011; Buffet et al., 2014), including pharmaceutical compounds (Maranho et al., 2015).

Adverse sublethal effects regarding physiological and biochemical responses after exposure of benthic species to different classes of pharmaceuticals (e.g. anti-inflammatory; oral contraceptive; anticonvulsant; antidepressant) were reported (Maranho et al., 2014, 2015). Biomarkers of behaviour impairment, neurotoxicity (acetylcholinesterase - AChE), antioxidant activity (superoxide dismutase - SOD; catalase - CAT; glutathione-peroxidases - GPx), biotransformation (glutathione-S-transferases - GST), oxidative damage (lipid peroxidation LPO) and genotoxicity (DNA strand breaks) were considered reliable endpoints to assess pharmaceuticals toxicity (Aguirre-Martínez et al., 2013; Gonzalez-Rey and Bebianno, 2013; Maranho et al., 2014, 2015). In this sense, the present study aims to assess the adverse effects of the CisPt anticancer drug to the ragworm $N$. diversicolor, at a range of relevant environmental scenarios (i.e. $0.1,10$ and $100 \mathrm{ng} \mathrm{Pt} \mathrm{L}^{-1}$ ). The approach involves the assessment of behavioural impairment (burrowing kinetic impairment), ion pump effects (SR $\mathrm{Ca}^{2+}$-ATPase), neurotoxicity (AChE activity), oxidative stress (SOD, CAT, GPXs activities), biotransformation (GST activities), metal exposure (metallothionein-like proteins - MTLPs), oxidative damage (LPO) and genotoxicity (DNA damage), after 14 days of exposure to a contaminated water-sediment system. To the best of our knowledge, this is one of the first multibiomarker approach encompassing anticancer drugs and marine organisms, with relevance to understand their risk in coastal and benthic habitats.

\section{Materials and methods}

\subsection{Chemicals}

Analytical standard of cis-platinum (II) diamine dichloride (CisPt) (CAS 15663-27-1) was obtained from Sigma-Aldrich (Portugal). CisPt stock solution (123.07 $\mathrm{mg} \mathrm{L}^{-1}$ ) was prepared in ultrapure Milli-Q water. For safety handling of cytotoxic drugs, experimental work was performed using class II biological safety cabinet, with appropriate clothing (open-back, impervious chemotherapy protection gown, double powder-free latex gloves and safety goggles). Test solution concentrations were selected according to a range of Pt-based anticancer drugs levels screened in waterbodies and effluents (Table 1) and were $0.1,10$

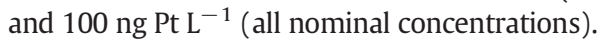

\subsection{Sediment characterization}

Sediments were sampled in the Ria Formosa lagoon (Tavira, Portugal), and sieved through a 2-mm mesh to remove large debris. Sediments were dried at $80{ }^{\circ} \mathrm{C}$ (adapted from ASTM, 2009; Thain and Bifield, 2001) to remove volatile compounds and water.

Grain size distribution was assessed on dry aliquots of sediments according to the method proposed by Royse (1970). Organic matter content was determined by loss on ignition $\left(550{ }^{\circ} \mathrm{C}\right.$, for $5 \mathrm{~h}$ ), by the method described by Gross (1971). Results obtained were $22.3 \%$ of sand, $77.7 \%$ of fines and $0.55 \%$ or organic matter content.

\subsection{Experimental design}

Specimens of $N$. diversicolor (5-7 cm length; $0.21 \mathrm{~g} \pm 0.06$ ) were supplied from an aquaculture of the Portuguese Institute of the Sea and Atmosphere (IPMA) (Tavira, Portugal) and transported alive to the laboratory in tanks with natural seawater and sediments and maintained at constant aeration for one week.

Twenty animals were randomly transferred to plastic aquaria of $10 \mathrm{~L}$ (each animal $/ 30 \mathrm{~cm}^{2}$ ), in a triplicate design, with a proportion of 1:4 sediments/water. Systems were kept under constant aeration and with a light period of 12:12 h. Natural seawater was renewed every $48 \mathrm{~h}$ followed by redosing of CisPt to maintain nominal concentrations in the water phase during the experiment. Physicochemical parameters: salinity, temperature and $\mathrm{pH}$ were determined in seawater (35.45 \pm $1.2 ; 18.3 \pm 0.8^{\circ} \mathrm{C} ; 7.99 \pm 0.07$, respectively). For each biochemical analysis (i.e. antioxidant enzymes; AChE; LPO and MT), measurements were carried out individually ( $\mathrm{n}=6$ per treatment). Animals were collected at the beginning of the experiment (Control (CT 0)) and after 14 days of exposure (Control (CT 14); 0.1, 10 and $100 \mathrm{ng} \mathrm{Pt} \mathrm{L}^{-1}$ ). Organisms used for behavioural ( $n=15$ per treatment) and comet assays $(n=15$ per treatment) were immediately handled, whereas those for biochemical endpoints were rinsed with clean seawater, frozen in liquid nitrogen and stored at $-80^{\circ} \mathrm{C}$ until further use.

\subsection{Sarcoplasmic reticulum $\mathrm{Ca}^{2+}-$ ATPase}

\subsubsection{Preparation of sarcoplasmic reticulum vesicles}

Isolated sarcoplasmic reticulum vesicles (SRV), prepared from freshly obtained skeletal rabbit muscles described elsewhere (Fraqueza et al., 2012a, 2012b) were suspended in $0.1 \mathrm{M} \mathrm{KCl}, 10 \mathrm{mM}$ HEPES ( $\mathrm{pH} 7.0$ ), diluted 1:1 with $2.0 \mathrm{M}$ sucrose and frozen in liquid nitrogen prior to storage at $-80^{\circ} \mathrm{C}$. Protein concentrations were determined spectrophotometrically at $595 \mathrm{~nm}$, by the Bradford method, using bovine serum albumin as a standard in the presence of $0.125 \%$ of sodium dodecyl sulphate (SDS). The percentage of each protein present in the SRV preparations was determined through densitometry analysis of SDS-polyacrylamide gel electrophoresis (7.5\% acrylamide). The SR $\mathrm{Ca}^{2+}$-ATPase analysed by SDS polyacrylamide gel electrophoresis comprised at least $70 \%$ of the total protein in the SR-vesicles. The SERCA-1, (sarcoplasmic, or endoplasmic reticulum $\mathrm{Ca}^{2+}$-ATPase-1) was the predominant isoform in the SR preparations (Fraqueza et al., 2012a).

\subsubsection{ATP hydrolysis by calcium pump}

Steady-state assays of the sarcoplasmic reticulum $\mathrm{Ca}^{2+}$-ATPase were measured spectrophotometrically at $25^{\circ} \mathrm{C}$ using the coupled enzyme pyruvate kinase/lactate dehydrogenase assay (Aureliano et al., 2008) under the following conditions: $25 \mathrm{mM}$ HEPES ( $\mathrm{pH} 7.0$ ), $100 \mathrm{mM} \mathrm{KCl}, 5 \mathrm{mM} \mathrm{MgCl}_{2}, 50 \mu \mathrm{M} \mathrm{CaCl}_{2}, 2.5 \mathrm{mM}$ ATP, $0.42 \mathrm{mM}$ phosphoenolpyruvate, $0.25 \mathrm{mM}$ NADH, 18 IU lactate dehydrogenase and $7.5 \mathrm{IU}$ pyruvate kinase, with or without CisPt. The experiments were initiated by the addition of $10 \mu \mathrm{g} / \mathrm{mL}$ calcium ATPase, in the presence or absence of $4 \%$ (w/w) of calcium ionophore A23187, and followed for $5 \mathrm{~min}$. CisPt concentrations (up to 4 and $8 \mathrm{mM}$ ) were added to the medium immediately prior to protein addition. Furthermore, within the concentration range studied, CisPt solutions did not affect the coupled enzyme method used in the assays, as observed upon addition of $40 \mu \mathrm{M}$ ADP.

Briefly, after the addition of the enzymes to the medium, NADH was added followed by the vesicles from skeletal muscle sarcoplasmic reticulum. Then, after the addition of ATP the absorbance was recorded during about $1 \mathrm{~min}$ (basal activity) and after the ionophore was added the decrease of the absorbance was measured during about 2 min (uncoupled ATPase activity). The ATPase activity and the inhibition of CisPt was measured taken into consideration the decrease of OD per 
minute in the absence (100\%) and in the presence of CisPt (Fraqueza et al., 2012b).

\subsection{Behaviour assay}

Unexposed and exposed worms for 14 days were submitted to a burrowing test according to Bonnard et al. (2009). Ten animals were carefully placed individually in $150 \mathrm{~mL}$-plastic containers, filled with natural seawater and $5 \mathrm{~cm}$ of sediments. Over a period of $30-\mathrm{min}$, the position of each worm was recorded every two minutes to establish the time that each worm was fully buried. The results are expressed as the percentage (\%) of unburied specimens over time (min).

\subsection{Biochemical analysis}

\subsubsection{Neurotoxicity}

For AChE activity determination, whole tissues were individually homogenized in $100 \mathrm{mM}$ Tris- $\mathrm{HCl}$ buffer ( $\mathrm{pH} 8$ ) containing Triton $0.1 \%$ and centrifuged at $12,000 \mathrm{~g}\left(30 \mathrm{~min}, 4^{\circ} \mathrm{C}\right)$. The supernatant was split into two $500 \mu \mathrm{L}$ aliquots for total protein determination and AChE activity. The assay was conducted by inserting the reaction mixture in each microplate well, containing $50 \mu \mathrm{L}$ of the sample, $0.75 \mathrm{mM}$ DTNB in $0.1 \mathrm{M}$ Tris $\mathrm{HCl}$, and $3 \mathrm{mM}$ acetylcholine (ATC). The method measures the absorbance of 5-mercapto-2-nitrobenzoato (yellow) (coefficient of extinction of $\varepsilon=13.6 \mathrm{mM}^{-1} \mathrm{~cm}^{-1}$ ) formed by the reaction of thiocholine, a product of ATC cleavage by AChE with DTNB, at $405 \mathrm{~nm}$ (Ellman et al., 1961; Colovic et al., 2013). AChE activity is expressed as ATC. $\mathrm{min}^{-1} \mathrm{mg}^{-1}$ protein.

\subsubsection{Antioxidant enzymes}

Tissues for the measurement of antioxidant enzymes were individually homogenized in $20 \mathrm{mM}$ Tris- $\mathrm{HCl}$ buffer $(0.5 \mathrm{M}$ sucrose, $0,075 \mathrm{M} \mathrm{KCl}$, $1 \mathrm{mM}$ DTT, $1 \mathrm{mM}$ EDTA), adjusted to $\mathrm{pH} 7.6$ and centrifuged at $500 \mathrm{~g}$ $\left(15 \mathrm{~min}, 4^{\circ} \mathrm{C}\right.$ ) to separate the cytosolic fraction. The supernatants were further re-centrifuged at $12,000 \mathrm{~g}\left(45 \mathrm{~min}, 4^{\circ} \mathrm{C}\right)$, to separate the mitochondrial fraction. Antioxidant enzymes activities were determined in the cytosolic fraction. SOD activity was analysed according to the method of McCord and Fridovich (1969), by measuring the decrease of absorbance of substrate cytochrome-c through xanthine oxidase/hypoxanthine system, at $550 \mathrm{~nm}$. Results are expressed as $\mathrm{U} \mathrm{mg}^{-1}$ protein. CAT activity was determined by spectrophotometry using a microplate reader by measuring the decrease of absorbance at $240 \mathrm{~nm}$ due to the presence of hydrogen peroxide concentration (Greenwald, 1985). CAT is expressed in $\mu \mathrm{mol} \mathrm{min}{ }^{-1} \mathrm{mg}^{-1}$ protein. Total GPX activity was measured in a microplate reader, at $340 \mathrm{~nm}$, based on the method adapted from Lawrence and Burk (1976). The reaction consists in the reduction of oxidized glutathione linked to the oxidation of NADPH in the presence of excess glutathione reductase. Cumene hydroperoxide and $\mathrm{H}_{2} \mathrm{O}_{2}$ were used as substrates for T-GPX and Se-GPX, respectively. Re-

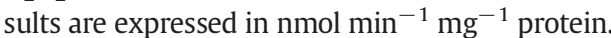

\subsubsection{Glutathione-S-transferases (GST)}

The activity of GST was measured in the spectrophotometric assay according to the method described by Habig et al. (1974). The conjugation of the worm samples with $0.2 \mathrm{mM}$ reduced glutathione (GSH) with $0.2 \mathrm{mM}$ 1-chloro-2,4-dinitrobenzene (CDNB) in a mixture of $0.2 \mathrm{M}$ $\mathrm{KH}_{2} \mathrm{PO}_{4} / \mathrm{K}_{2} \mathrm{PO}_{4}$ buffer ( $\mathrm{pH} 7.9$ ) was measured, with a molar extinction coefficient $(\varepsilon)$ of $0.6 \mathrm{mM}^{-1} \mathrm{~cm}^{-1}$. The change in absorbance was recorded at $340 \mathrm{~nm}$. GST activity is expressed in $\mathrm{nmol} \mathrm{min}^{-1} \mathrm{mg}^{-1}$ protein.

\subsubsection{Metallothionein-like proteins (MTLPS)}

Whole tissues of $N$. diversicolor were individually homogenized in Tris- $\mathrm{HCl}$ buffer $(0.02 \mathrm{M}, \mathrm{pH}$ 8.6) and BHT ( $10 \mu \mathrm{L}$ BHT per $\mathrm{mL}$ Tris- $\mathrm{HCl}$ buffer). The homogenate was centrifuged at $30,000 \mathrm{~g}$ for $45 \mathrm{~min}\left(4^{\circ} \mathrm{C}\right)$. Aliquots of the supernatant were separated for further use in LPO and total proteins quantification (Cravo et al., 2012). The remaining supernatant was heat-treated at $80^{\circ} \mathrm{C}$ for $10 \mathrm{~min}$ to precipitate the high molecular weight proteins, and re-centrifuged at $30,000 \mathrm{~g}$ for $45 \mathrm{~min}$ at $4{ }^{\circ} \mathrm{C}$. The obtained cytosolic fraction was stored at $-80^{\circ} \mathrm{C}$ for MTLPs quantification by differential pulse polarography according to the method described by Bebianno and Langston (1989). Levels of MTLPs are expressed as $\mathrm{mg} \mathrm{mg}^{-1}$ protein.

\subsubsection{Oxidative damage}

LPO was assessed by determining the absorbance of malondialdehyde (MDA) and 4-hydroxyalkenals (4-HNE) concentrations, at $540 \mathrm{~nm}$, following the method described by Erdelmeier et al. (1998), adapted for microplate reader. LPO is expressed as nmol MDA + 4-HNE $\mathrm{mg}^{-1}$ protein.

\subsubsection{Total proteins concentration}

Total proteins concentration was determined following the method described by Bradford (1976), adapted for microplate reader using bovine serum albumin (BSA) as a standard.

\subsection{Genotoxicity assay}

Genotoxicity endpoint was assessed by the Comet assay, based on the slightly modified protocol of Singh et al. (1988), and described in Gomes et al. (2013). Extraction of the polychaetes coelomocytes was performed at the beginning and end of the exposure period, according to Lewis and Galloway (2008). Briefly, coelomic fluid of N. diversicolor $(\mathrm{n}=15)$ was extracted from the posterior region of the polychaete body into $20 \mu \mathrm{L}$ of PBS buffer with a $0.5 \mathrm{~mL}$-syringe fitted with hypodermic needle. The mixture was centrifuged at $835 \mathrm{~g}\left(3 \mathrm{~min}, 4^{\circ} \mathrm{C}\right.$ ), and the pellets were used for the comet assay. Slides were previously cleaned in alcohol/ether and coated with $0.65 \%$ normal melting point agarose (NMA) in Tris-acetate EDTA. Isolated cells from centrifugation were suspended in $0.65 \%$ low melting point agarose (LMA, in Kenny's salt solution; $0.4 \mathrm{M} \mathrm{NaCl}, 9 \mathrm{mM} \mathrm{KCl}, 0.7 \mathrm{mM} \mathrm{KH}_{2} \mathrm{PO}_{4}, 2 \mathrm{Mm} \mathrm{NaHCO}_{3}, 1000 \mathrm{~mL}$ Milli-Q water) and casted on the microscope slides. Then slides with the embedded cells were immersed for $1 \mathrm{~h}$, in a lysis buffer (100 mM EDTA, $2.5 \mathrm{M} \mathrm{NaCl}, 10 \mathrm{mM}$ Tris, $1 \%$ Triton X-100, 10\% Dimethylsulfoxide,1\% Sarcosil, $\mathrm{pH} 10,4^{\circ} \mathrm{C}$ ) for the diffusion of cellular components and DNA immobilization in agarose. Following the lysis step, slides were gently placed in an electrophoresis chamber containing electrophoresis buffer ( $300 \mathrm{mM} \mathrm{NaOH}, 1 \mathrm{mM}$ EDTA, adjusted at $\mathrm{pH} 13,4^{\circ} \mathrm{C}$ ) and left for $15 \mathrm{~min}$ to permit DNA unwinding. The electrophoresis was performed at $25 \mathrm{~V}$ and $300 \mathrm{~mA}$, over $5 \mathrm{~min}$.

Afterwards, microscope slides were soaked with neutralizing solution (0.4 mM Tris, pH 7.5), for $15 \mathrm{~min}$, and finally rinsed with distilled water and dryed overnight. For further comets assessment, slides were stained with 4,6-diamidino-2-phenylindole (DAPI, $1 \mathrm{mg} \mathrm{ml}^{-1}$ ) and analysis made through optical fluorescence microscope (Axiovert S100) coupled with a camera (Sony). The image analysis system Komet 5.5 (Kinetic Imaging Ltd) was used to score 50 randomly chosen cells for each slide ( 25 in each gel from each individual) at a total magnification of $\times 400$. The amount of DNA in the comet tail (tail DNA \%) was used and results are expressed as mean \pm SEM.

\subsection{Statistical analysis}

Data was tested for normality and homogeneity of variance by Kolmogorov-Smirnov and Brown-Forsyth tests, respectively. Once these assumptions were tested, one-way analysis of variance (ANOVA or non-parametric Kruskal-Wallis test) was performed. As a result of these tests all data, except GPx, was treated as parametric. The posthoc Tukey test for multiple data comparisons was applied to discriminate significant differences among treatments $(p<0.05)$. Behavioural status of organisms was analysed by linear regression, considering the interval of continuous burrowing in the sediments. Principal 


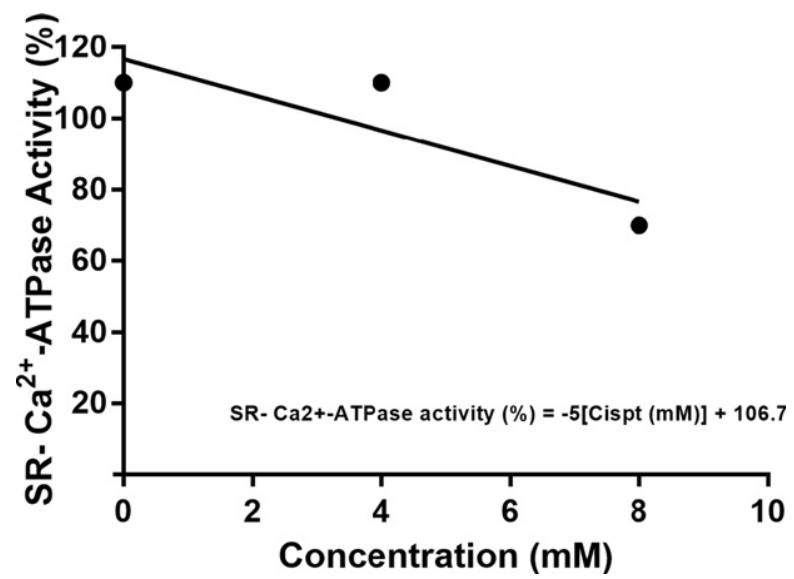

Fig. 1. Inhibition of sarcoplasmic reticulum calcium pump by CisPt.

component analysis (PCA) was used to evaluate the influence CisPt concentrations on biochemical biomarkers and DNA damage, in control and exposed polychaetes. Statistical analysis was conducted with GraphPad Prism ${ }^{\circledR}$ software (v. 6, 2014) and PAST ${ }^{\circledR}$ software (v. 3.10, 2015).

\section{Results}

\subsection{Effects of CisPt in $\mathrm{Ca}^{2+}$-ATPase activity}

Sarcoplasmic reticulum (SR) plays a crucial role in calcium homeostasis and in regulating muscle contraction. Sensitivity of SR $\mathrm{Ca}^{2+-}$ ATPase activity has been documented by the increase of basal cytosolic $\mathrm{Ca}^{2+}$ concentration after incubation with toxic and/or contaminant metals solutions (Aureliano and Crans, 2009). In the present study, the inhibition of the SR $\mathrm{Ca}^{2+}$-ATPase activity by CisPt was analysed to relative higher concentrations ( $8 \mathrm{mM}$ ) of CisPt.

As observed in Fig. 1, even for concentrations up to $8 \mathrm{mM}$ of CisPt, the activity of the calcium pump was only inhibited about $40 \%$. For this ion pump activity, it was estimated an $\mathrm{IC}_{50}$ of about $13.7 \mathrm{mM}$ for CisPt solutions.

\subsection{Behavioural assay}

Burrowing behaviour of polychaetes over time is presented in Fig. 2 . Linear regression showed no significant differences among slopes in the burrowing of worms exposed to the different treatments $(p>0.05)$. Nevertheless, a similar trend of burrowing kinetic was observed between unexposed organisms $(\mathrm{Y}=-12 \times+106 ; \mathrm{r}=0.97 ; p<0.05)$ and those exposed to $0.1 \mathrm{ng} \mathrm{Pt} \mathrm{L}^{-1}(\mathrm{Y}=-14 \times+114$; $\mathrm{r}=0.9615$;

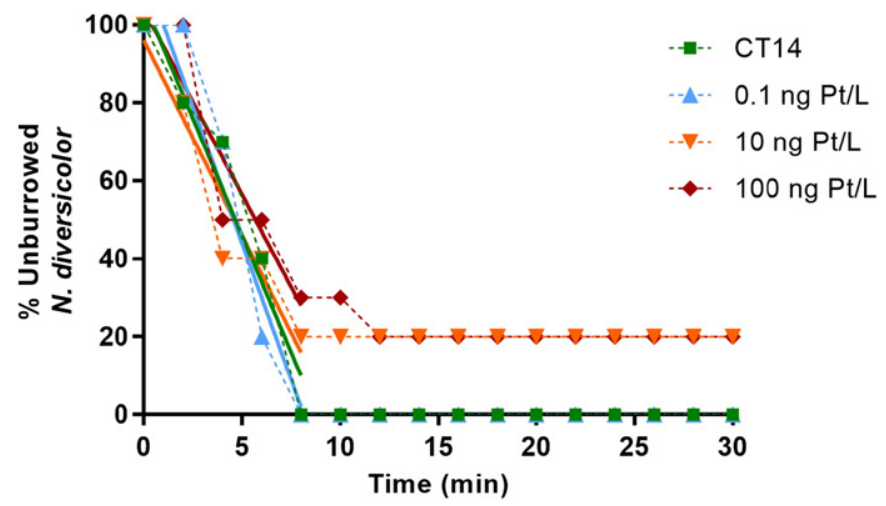

Fig. 2. Burrowing behaviour of $N$. diversicolor unexposed (CT14 - control at day 14) and exposed to CisPt $\left(0.1,10\right.$ and $\left.100 \mathrm{ng} \mathrm{Pt} \mathrm{L}^{-1}\right)$ for 14 days, expressed as percentage of unburrowed organisms over time (minutes).

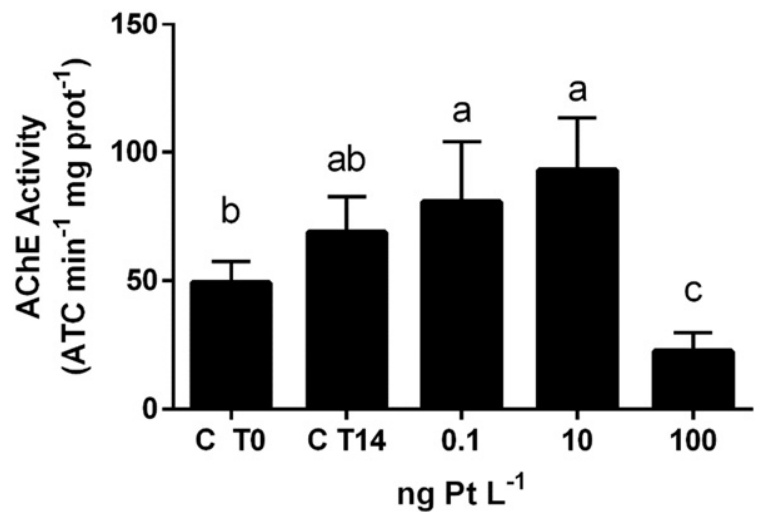

Fig. 3. AChE activity (mean \pm standard deviation) (ATC $\mathrm{min}^{-1} \mathrm{mg}^{-1}$ protein) in $\mathrm{N}$. diversicolor unexposed (CT0 and CT14) and exposed to CisPt $\left(0.1,10\right.$ and $100 \mathrm{ng} \mathrm{Pt} \mathrm{L}^{-1}$ ) for 14 days. Different letters indicate statistically significant differences among treatments (One-way ANOVA; $p<0.05$ ).

$p<0.05)$, where all polychaetes were fully buried after 8 min. Meanwhile, specimens exposed to $10(\mathrm{Y}=-10 \times+106 ; \mathrm{r}=0.96$; $p<0.05)$ and $100 \mathrm{ng} \mathrm{Pt} \mathrm{L}{ }^{-1}(\mathrm{Y}=-7.1 \times+97.14 ; \mathrm{r}=0.93 ; p<0.05)$ showed a slower burrowing rate, with organisms unable to burrow the sediment by the end of the assay.

\subsection{Biochemical analysis}

\subsubsection{Neurotoxicity}

Results of AChE activity are expressed in Fig. 3. AChE levels were similar between controls over time $(p>0.05)$. An increasing trend

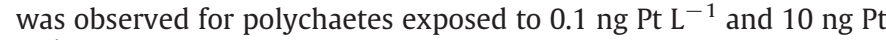
$\mathrm{L}^{-1}$ although not significantly different from controls $(p>0.05)$. Polychaetes exposed to $100 \mathrm{ng} \mathrm{Pt} \mathrm{L}^{-1}$ showed a significant inhibition of AChE activity compared to controls $(p>0.05)$.

\subsubsection{Antioxidant enzymes}

In the present study, antioxidant enzymes of control polychaetes did not change over time $(p>0.05)$. SOD activity showed a significant inhibition (i.e 2.3-fold) in worms exposed to $100 \mathrm{ng} \mathrm{Pt} \mathrm{L}^{-1}(p<0.05)$ (Fig. $4 \mathrm{~A})$. Similarly, exposure to the highest CisPt concentration resulted in a clear inhibition (i.e. 2.3-fold) of CAT activity $(p<0.05)$ (Fig. 4B). In contrast, CisPt yielded a significant increase in GPx Se-dependent activity and levels ranged from $0.05 \pm 0.01 \mathrm{nmol} \mathrm{min}{ }^{-1} \mathrm{mg}^{-1}$ protein to $0.22 \pm 0.07 \mathrm{nmol} \mathrm{min}{ }^{-1} \mathrm{mg}^{-1}$ protein for worms exposed to $100 \mathrm{ng}$ Pt L $^{-1}(p<0.05)$ (Fig. 4C). Regarding T-GPx, the activity indicated a bell-shape behaviour, where the activity of this enzyme was significantly inhibited after $0.1 \mathrm{ng} \mathrm{Pt} \mathrm{\textrm {L } ^ { - 1 }}$ exposure and induced after $100 \mathrm{ng} \mathrm{Pt} \mathrm{L}{ }^{-1}$ exposure (Fig. 4D) $(p<0.05)$. Furthermore, GST activity was only inhibited at the highest CisPt concentration $(p<0.05)$ (Fig. 4E).

\subsubsection{Metallothionein-like proteins (MTLPS)}

Results showed a significant increase in MTLPs levels $(p<0.05)$ only at the highest CisPt concentration (100 ng Pt $\mathrm{L}^{-1}$ ), accounting for a 2fold increase when compared to controls (Fig. 4F).

\subsubsection{Oxidative damage}

LPO products over the exposure conditions presented an increasing trend but only significant at the highest drug concentration compared to controls $(p<0.05)$ (Fig. 5).

\subsection{Genotoxicity}

Genotoxicity data, expressed as percentage of DNA tail, are presented in Fig. 6. No changes in DNA damage were observed for any treatment $(p>0.05)$. 

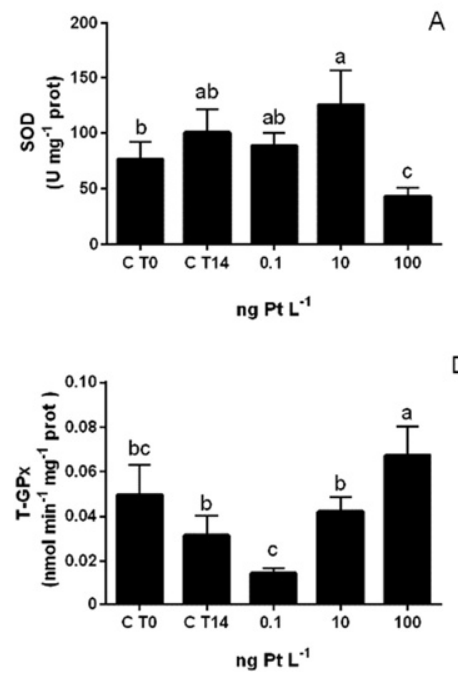

B
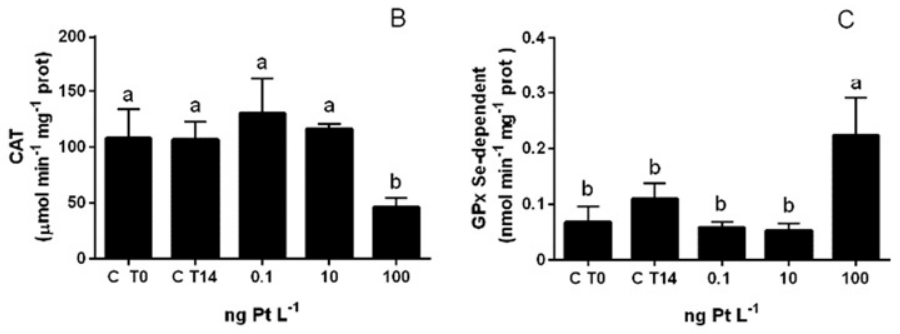

$\mathrm{E}$

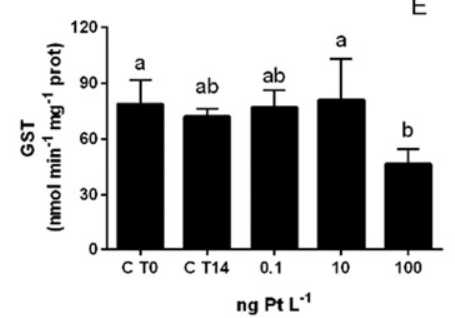

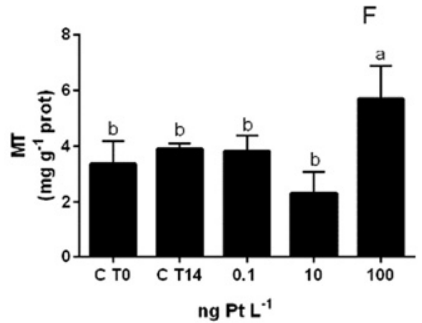

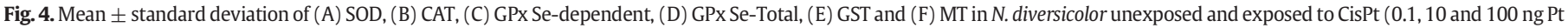
$\mathrm{L}^{-1}$ ) for 14 days. Different letters indicate statistically significant differences among treatments (One-way ANOVA (A, B, C, D, F) and Kruskal Wallis (E); $p<0.05$ ).

\subsection{Principal component analysis (PCA)}

Biochemical biomarkers and genotoxicity data were integrated in a multivariate analysis in order to detect patterns of variation. PCA results indicated that the two principal components represent $89.8 \%$ of total variance $(\mathrm{PC} 1=75.6 \%$; $\mathrm{PC} 2=14.2 \%$ ). High correlation loadings in the first component indicated that antioxidant enzymes SOD, CAT, GST and AChE activity were inhibited at the highest CisPt level (i.e. $100 \mathrm{ng}$ $\mathrm{Pt} \mathrm{L}^{-1}$ ). SOD and CAT neutralize ROS, and their decrease together with GST reduction favor the depletion of cell defenses while Se-GPx, MT and LPO were the opposite. The second component indicates a relationship between LPO and genotoxicity endpoints. The overall PCA clear

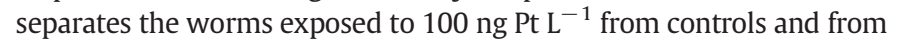
those exposed to the lower CisPt concentrations. Moreover, worms exposed to $0.1 \mathrm{ng} \mathrm{Pt} \mathrm{L}^{-1}$ were closely associated to those for controls, reflecting the effectiveness of antioxidant systems and absence of harmful effects at this level of CisPt concentration.

\section{Discussion}

CisPt is widely used for treatment of different types of tumours including head and neck, lung, ovarian, leukaemia, breast, brain, kidney

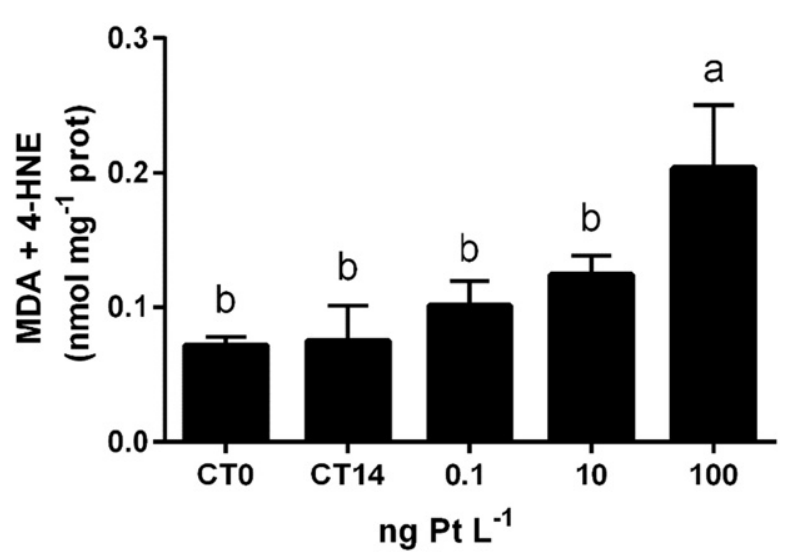

Fig. 5. LPO activity (mean \pm standard deviation) (MDA +4 -HNE nmol mg ${ }^{-1}$ protein $)$ in $N$. diversicolor unexposed (CT0 and CT14) and exposed to CisPt $\left(0.1,10\right.$ and $\left.100 \mathrm{ng} \mathrm{Pt} \mathrm{L}^{-1}\right)$ for 14 days. Different letters indicate statistically significant difference among treatments (One-way ANOVA; $p<0.05$ ). and testicular cancers (Dasari and Bernard Tchounwou, 2014). CisPt acts in mammals over the N7 centres of purine residues, especially guanine, mainly generating 1,2-intrastrand $d(\mathrm{GpG})$ adducts and 1,2intrastrand $d(A p G)$, besides the enhancement of oxidative stress and damage in mitochondrial proteins, which result in an overall failure of cellular function and apoptosis (Chu, 1994; Reedijk, 1999; Dasari and Bernard Tchounwou, 2014). The drug's MoA and toxicity was extensively studied in mammals, where ototoxicity, nephrotoxicity and gastro toxicity are the main side effects (Karasawa and Steyger, 2015). The diffuse, worldwide and frequent discharge of effluents containing cytotoxic drugs in coastal waterbodies brings ecological and environmental concern regarding the chronic exposure of these chemicals to biota, even at low concentrations. Ecotoxicological assays with anticancer drugs in aquatic organisms are now emerging, although approaches with marine benthic species are lacking.

In the present study, the effects of CisPt on the function of the sarcoplasmic reticulum $\mathrm{Ca}^{2+-}$ ATPase were investigated to evaluate putative effects on calcium homeostasis. It was assumed that the onset of contraction in polychaetes muscle is triggered by similar mechanisms as in vertebrates, once previous studies have shown that energy transduction catalysed by $\mathrm{Ca}^{2+}$-ATPase is highly conserved through evolution, as observed in marine invertebrates (Garcia et al., 1975; Cario et al., 1995;

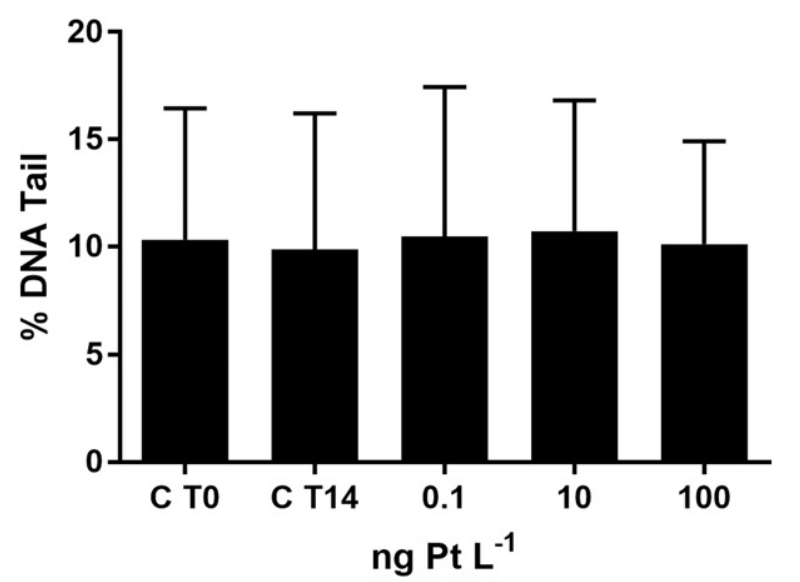

Fig. 6. DNA (mean \pm standard deviation) in tail, in $N$. diversicolor unexposed (CTO and

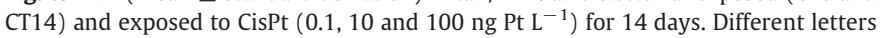
indicate statistically significant differences among treatments (One-way ANOVA; $p<0.05$ ). 
Landeira-Fernandez, 2001). CisPt had no effect on $\mathrm{Ca}^{2+}$-ATPase activity in particular for the CisPt concentrations normally found in the environment (Fig. 1). Therefore, inhibition of $\mathrm{Ca}^{2+}$-ATPase activity by cisplatin seems unlikely as a cause of CisPt toxicity, although CisPt can decrease ATPase activity in vitro. Others studies estimated $\mathrm{IC}_{50}$ values in the order of 2 to $5 \mathrm{mM}$ for similar ion pumps, but for longer incubation periods such as $2 \mathrm{~h}$ (Uozumi and Litterst, 1985). However, the lower ATPase activity inhibition by CisPt can, at least in part, be due to the solvent (DMSO) used. It can react with CisPt and therefore and in this situation is not a good solvent. Recently it was reported that $\mathrm{IC}_{50}$ values increased up to about 10- and 60-fold, respectively, for carboplatin and cisplatin prepared in DMSO whereas no effects were observed for others Pt complexes such as oxaliplatin and satraplatin (Hall et al., 2014). Therefore, certain precautions should be taken when using solvents in in vitro and in vivo Pt drugs studies. The multibiomarker approach linking behavioural, biochemical and genotoxicity endpoints provide important information about the impact caused by pollutants in aquatic organisms (Durou et al., 2007; Gusso-Choueri et al., 2016). Burrowing impairment comprises an ecological valuable biomarker of stress reflecting disturbances in organisms fitness, such as food seeking and predator avoidance (Bonnard et al., 2009). The suitability of burrowing behaviour is a reliable and sensitive biomarker when defence mechanisms are not enough to prevent impairments (Amiard-Triquet, 2009; Buffet et al., 2012). N. diversicolor plays an important ecological role due to bioturbation, that provides irrigation and particle mixing via burrowing and feeding (Thit et al., 2015). Alteration of such behaviour provide harmful ecological outcomes (Bonnard et al., 2009). In addition, increase of burrowing time may facilitate worm predation on the sediment surface (Amiard-Triquet, 2009). Results on behaviour (Fig. 2) clearly indicate a perturbation on burrowing of organisms exposed to the highest CisPt concentration (100 ng Pt L ${ }^{-1}$ ) that were not fully buried by the end of the assay (Fig. 2). To date, burrowing responses of endobenthic organisms after exposure to pharmaceuticals are lacking. Meanwhile, Cong et al. (2014) addressed an increase in burrowing time in specimens of $N$. diversicolor exposed to $\mathrm{Ag}$ nanoparticles, at concentrations of 50 and $100 \mu \mathrm{g} \mathrm{Ag} \mathrm{mg}{ }^{-1} \mathrm{~d} . \mathrm{w}$. in the sediments, corroborating with high cytotoxic and genotoxic potential of Ag nanoparticles on burrowing behaviour. Decrease burrowing of $N$. diversicolor, compared to controls, was also observed after exposure to copper (Buffet et al., 2011; Thit et al., 2015) and sediment-spiked CuO NPs (Thit et al., 2015).

Alteration of behaviour and locomotion may be a response to neurotransmitters inhibition, which play a key role in the nervous system (Boyd et al., 2002; Bonnard et al., 2009). AChE activity is vital for normal muscular function and behaviour of most species, because it is involved in the nervous transmission by a rapid hydrolysis of the neurotransmitter acetylcholine in acetate and choline at the nervous systems (Payne et al., 1996; Cajaraville et al., 2000). Inhibition of AChE is well-recognized as a biomarker of exposure to neurotoxic compounds (Damásio et al., 2011; Aguirre-Martínez et al., 2016). Herein, AChE levels in-

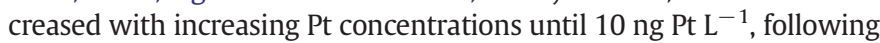
a strongly inhibition at the highest CisPt concentration (100 ng Pt $\mathrm{L}^{-1}$ ) (Fig. 3). This behaviour depicts a hormesis phenomenon, comprised by the stimulation of a response (AChE activity) at a dose below the pharmacological/toxicological threshold (Calabrese and Blain, 2005; Aguirre-Martínez et al., 2016) that is in an attempt to mitigate the neurotoxic effects against the transitory drug effect (Milan et al., 2013; Aguirre-Martínez et al., 2016). According to Calabrese and Baldwin (2001) it is an adaptive response that results in an improved physiological fitness, for a finite and generally short period. In this sense, behavioural interferences at $10 \mathrm{ng} \mathrm{Pt} \mathrm{L}^{-1}$ may be associated to such mitigation effort, whereas at $100 \mathrm{ng} \mathrm{Pt} \mathrm{\textrm {L } ^ { - 1 }}$ it may be due to AChE inhibition, thus neurotoxicity (Milan et al., 2013; Aguirre-Martínez et al., 2016). A similar upregulation followed by an inhibition of AChE activity was observed in the clam Ruditapes philippinarum after exposure to caffeine (5 to $50 \mu \mathrm{g} \mathrm{L}^{-1}$ ) and carbamazepine ( 0.1 to $50 \mu \mathrm{g} \mathrm{L}^{-1}$ ) for 14 days (Aguirre-Martínez et al., 2016). This trend was also addressed at fluoxetine exposure using the clam Venerupis philippinarum ( 1 and $5 \mu^{-1} \mathrm{~L}^{-1}$; Munari et al., 2014) and the mussel Mytillus galloprovincialis ( $75 \mathrm{ng} \mathrm{L}^{-1}$; Gonzalez-Rey and Bebianno, 2013).

Levels of AChE activity in $N$. diversicolor also increase significantly after 14 day-exposure to sediment spiked with ibuprofen, carbamazepine, fluoxetine and EE2, showing a situation where hormesis did not occur, due to a combination of the test organisms, dose and pharmaceutical compounds selected (Cossu et al., 2000; Gonzalez-Rey and Bebianno, 2013; Aguirre-Martínez et al., 2016; Maranho et al., 2015). CisPt is an organo-metallic compound designed to perform neurological side-effects in human erythrocytes, arising neurotoxicity as an effect of interaction of the molecule with AChE (Aljafari, 1995). According to Bhagavan (2002), AChE substrates are subject to a nucleophilic attack by the oxygen atom of the seryl hydroxyl group present in this enzyme. The electrophilic reactive products of hydrolysis, containing Pt may be the key factor for the inhibition of AChE activity and this may be the case in the worms exposed to the highest CisPt concentration.

CisPt hydrolysed species are strongly electrophilic and can react with nucleophile binding sites, including the thiol groups $\mathrm{SH}$ - of biomolecules. In this sense, the nucleophile reduced glutathione (GSH) is one of the main target of CisPt drug (Gonzalez et al., 2001), and acts as a protection ligand against drug toxicity and side effects without interfering in the antitumor activity (Reedijk, 1999). It has an important role in regulation of inner mitochondrial permeability and enzyme function by keeping $\mathrm{SH}$ - in the reduced state, thus acting on protection against oxidative stress (Reedijk, 1999). GSH reacts with CisPt and other electrophilic compounds to form deactivated conjugates that are readily excreted by a GS-conjugated export pump. This reaction may occur spontaneously or with the enzymatic help of GST (Fuertes et al., 2003; Penner and Prakash, 2010). GSH depletion in cells may lead to the reduction of GST activity, as observed in worms exposed to $100 \mathrm{ng} \mathrm{Pt}$ $\mathrm{L}^{-1}$ (Fig. 4E). In addition, CisPt-GSH conjugation generates thiyl radicals (RS•) able to produce reactive oxygen species (ROS) (Slater, 1984; Desoize, 2002; Aquilano et al., 2014).

In order to prevent ROS interaction with critical cellular macromolecules, SOD plays the primary defence role against oxygen toxicity by

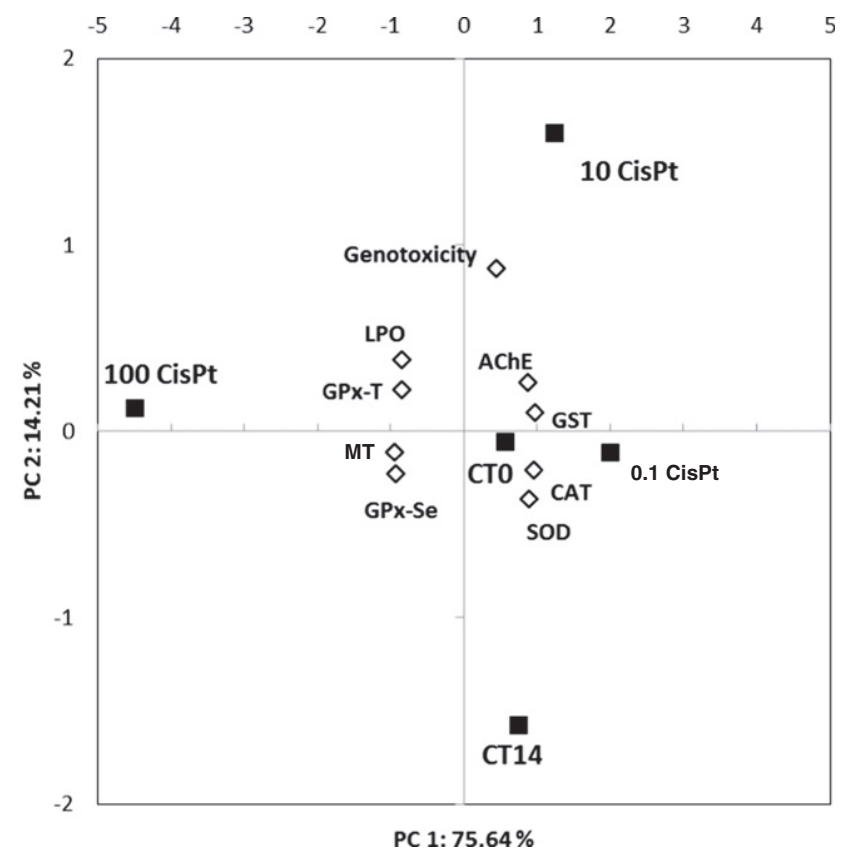

Fig. 7. Principal Component Analysis (PCA) of biochemical biomarkers and DNA damage analysed in $N$. diversicolor at controls (CTO and CT14) and CisPt-contaminated conditions, for 14 days. 
catalyzing the conversion of $\mathrm{O}_{2}^{-}$, to $\mathrm{H}_{2} \mathrm{O}_{2}$ through dismutation reaction, while CAT degrades $\mathrm{H}_{2} \mathrm{O}_{2}$ to $\mathrm{H}_{2} \mathrm{O}$ (Van den Berg et al., 2005). In the present study, the significant decrease of both enzyme activities in worms exposed to the highest CisPt concentration (Fig. 4) indicate an impairment of their activity that could be attributed to a possible excess of reactive oxygen intermediate species. Hence, the increase of Se-GPx in worms exposed to $100 \mathrm{ng} \mathrm{Pt} \mathrm{L}^{-1}$ may be a response to counteract the impairment of hydrogen peroxide metabolism, usually provided by SOD and further generation of pro-oxidant products required for neutralization (Catalano et al., 2012; Gomes et al., 2014). Se-GPx acts by reducing organic peroxides and is known as a critical tool to mitigate oxidative stress caused by a wide diversity of electrophilic species (Prabhu et al., 2004).

Previous biochemical approaches using $N$. diversicolor indicated a noteworthy responsiveness of antioxidant system to contaminated sediments (Durou et al., 2007; Kalman et al., 2009; Maranho et al., 2014). The trend of detoxification process encompasses the increment of GST and of CAT levels, which might suggest a relationship between those enzymes playing their role against oxidative stress, due to an improvement of neuromuscular status and the absence of LPO products (Solé et al., 2009; Buffet et al., 2011; Buffet et al., 2014). In the present study, the first axis of PCA (75.6\%) supports the connected mechanisms of biochemical impairments but does not occur in worms exposed to the higher concentration where a clear inhibition of SOD, CAT and GST indicate a lack of enough protection against ROS, neurotoxicity and membrane damage, as supported by the PCA analysis (Fig. 7). The deficiency on enzymatic activities in the worms exposed to the highest CisPt concentration suggest a precarious state of biochemical conditions, promoting a high susceptibility for biological systems (Cossu et al., 2000), as observed in burrowing behaviour, and propensity to lipid peroxide generation (Buffet et al., 2012).

The induction of MTLP was recognized as a potential biomarker of metal exposure in aquatic organisms (Amiard et al., 2006; Won et al., 2008). These cysteine-rich metal-binding proteins act on metal detoxification and homeostasis by forming inactive complexes with metal in the cytosol or excreted through their thiol groups (Gagné et al., 2008; Won et al., 2008; Huska et al., 2009). The presence of MTLPs in annelids was addressed by several authors (Geracitano et al., 2004; Pérez et al., 2004; Poirier, 2006; Won et al., 2008). However, previous studies reported no significant relationship between MTLP induction and the overall metal concentrations in $N$. diversicolor, suggesting that this biomarker does not reflect metal bioavailability on this biological model (Poirier, 2006; Gomes et al., 2013). Comprehension of functional genomic and transcriptomic responses of MTLPs in ragworms was first described by McQuillan et al. (2014), which identify two putative MTLP genes encoding cysteine-rich proteins (i.e. Cd/Se MT and atypical MTLP), after Cu long-term exposure. In the present study, MTLP levels significantly increased in worms exposed to the highest CisPt concentration (i.e. $100 \mathrm{ng}$ CisPt $\mathrm{L}^{-1}$ ) (Fig. 4). On the route to DNA attack, CisPt species interact with biomolecules containing methionine and cysteine residues (Reedijk, 1999), followed by an increase of the levels the thiol-containing proteins (Jamieson and Lippard, 1999; Siddik, 2003; Supalkova et al., 2008). MTLP overexpression seems to be a useful cellular defence against CisPt and is implicated in drug resistance to different chemotherapies by decreasing the level of the antitumor agent available for interaction with the target DNA (Doz et al., 1993; Hagrman et al., 2003; Smith et al., 2006). Besides evidence on modulation of drug responses, MTLPs also mediate a decrease in toxicity of CisPt (Jamieson and Lippard, 1999).

Despite the remarkable binding strength of GSH to CisPt and outcomes in drug resistance, MTLPs trap on the drug molecule is significantly higher and limits the amount of the drug available for binding to DNA (Doz et al., 1993; Fuertes et al., 2003; Hagrman et al., 2003).

In this sense, MTLPs indicate a potential antioxidant performance regarding electrophilic cytotoxic agents (Doz et al., 1993; Geret et al., 2003; Gagné et al., 2008) for the highest CisPt concentration, induced by the decrease of the other antioxidant enzymes activity. Likewise, levels of LPO increased with the increasing CisPt concentration (Fig. 5), but were only significant at $100 \mathrm{ng} \mathrm{Pt} \mathrm{L}^{-1}$ confirming a decrease in the antioxidant lines of defence, leading to alterations such as protein degradation and membrane damage (Viarengo et al., 1990; Viarengo et al., 2007; Gomes et al., 2014). Consequently, unpaired electrons in the lipid molecules give rise to hydroperoxide radicals, able to trigger chain reactions based on assemblage of electrons from other lipid structures. The LPO pathway may also arise from the depletion of GSH and NADH resulting in dehydrogenase inhibition and uncoupling of oxidative phosphorylation (Dasari and Bernard Tchounwou, 2014). This process leads to hydroxyl radical formation and more oxidative stress. The decrease of the activity of GST enzymes implies the need to protect cells against peroxides (Hurst et al., 1998). In this sense, the action of Se-GPX is an important alternative to counteract harmful electrophiles produced during oxidative damage (Fig. 7). Despite the increase in SeGPx activity, the defence pathway is not enough in particular for the worms exposed to the highest concentration, as accounted in PCA by the positive relationship between both Se-GPX and LPO products (Fig. 7 ). The detection of genotoxic alterations caused by exposure to cytotoxic drugs at environmental conditions could be of great relevance to address aquatic ecotoxicological impacts. Polychaetes are highly sensitive to genotoxic damage (Lewis and Galloway, 2008; Catalano et al., 2012; Buffet et al., 2013; Maranho et al., 2014). Agents such as CisPt binds covalently to base residues on DNA strands producing DNA-DNA intra- and inter-strand cross-links (ICLs) (Siddik, 2003) that, respectively, comprise the link of two nucleotides in the same and opposite strands (Deans and West, 2011). Intra and inter-strand cross-links binds strongly to prevent DNA strands separation, thus blocking DNA replication and transcription (Jamieson and Lippard, 1999; Noll et al., 2006; Deans and West 2011). The absence of detection of the double and single strand breaks in CisPt contaminated worms, assessed by alkaline comet assay, may be attributed to the presence of ICLs and DNA-DNA intra-strand crosslinks, leading to the closure of DNA strands and less DNA migration in electrophoresis (Merk and Speit, 1999). Contrarily, genotoxicity outcome by strand breaks formation occurred in freshwater daphnids Daphnia magna and Ceriodaphnia dubia exposed to CisPt (100 ng L ${ }^{-1}$ and $300 \mathrm{ng} \mathrm{L}^{-1}$, respectively) over $24 \mathrm{~h}$ (Parrella et al., 2015). DNA damage was also present throughout the 14 days of

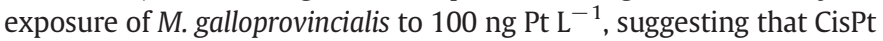
exerts its toxic effects probably by direct breaking of DNA strands and ROS production (Trombini et al., 2016). In general, CisPt induces DNA repair mechanisms to remove adducts and promote cell survival, by stalling the helix distorting occasioned by chemotherapeutic drugs and UV radiation (Siddik, 2003). Through the SOS chromotest, CisPt drug was recognized as a potent inducer of SOS reparation system in Escherichia coli PQ37, where DNA repair mechanism and recombinant enzymes were expressed (Lantzsch and Gebel, 1997; Nowosielska et al., 2004; Parrella et al., 2015). Thus, certain mutations of genes responsible for repair pathways inherent to each species may be prone to generate differences in sensitivity to cytotoxic drugs (Huang and Li, 2013) that need to be confirmed in this case.

Still, the absence of genotoxicity, in the present study, may also arise from the remarkable induction of antioxidant potential at the highest drug concentration, acting to supply the overwhelmed enzymes activity against CisPt toxicity. In addition, the nucleophilic trapping capacity of MTLP and GSH to CisPt are widely known to contribute to resistance to the drug, once its availability to nucleus is reduced (Doz et al., 1993).

According to the European Medicine Evaluation Agency (EMEA) guidelines, ecotoxicological assays with representative aquatic species of each trophic level must be performed to screen and assess environmental risk posed by drugs (EMEA, 2006). Nevertheless, these bioassays are only required for pharmaceuticals under processes for production authorization and market implementation, which discard anticancer drugs for the submission to such a procedure (Besse et al., 2012). Besides, very few studies exist that apply the biochemical, metabolic and 
physiological responses in aquatic organisms exposed to chronic environmental realistic concentrations (Fent et al., 2006; Maranho et al., 2014).

This study clearly demonstrates the response of multibiomarker approach involved in behaviour assessment, oxidative stress and genotoxic responses that are consistent to the MoA of this drug in this species. Despite that the responses addressed are mostly depicted at the highest CisPt concentration, Pt concentration at $\mathrm{ng} \mathrm{L}^{-1}$ range reflects that very low concentrations combined with chronic exposure may represent a hazard for aquatic species. In addition, the bioassay was conducted with only one pharmaceutical compound, whereas a mixture of several other compounds with similar and different MoA towards anticancer activity, also at low concentrations, have already been detected in coastal waters (Besse et al., 2012). The present approach and exposure stands out of a standardized and classic biotest applied for regulatory considerations, and holds significance based on the reality and complexity of the benthic aquatic environment, including the environmentally realistic concentrations of the chosen drug.

\section{Conclusions}

To the best of our knowledge, this is the first (eco)toxicity assessment dealing with cytotoxic drugs between water and sediment compartments. The present study indicates that CisPt has the potential to induce neurotoxic effects that may alter the burrowing profile of polychaetes. Inhibition of antioxidant enzymes activity (SOD, CAT) and biotransformation (GST) and potential accumulation of pro-oxidant radicals led to stress able to further increase membrane susceptibility to lipid peroxidation. These biological alterations were only observed at highest CisPt levels, which if detected in the environment may depict a high biological risk. Nevertheless, the lack of enough biochemical protection to prevent impairment was verified at $\mathrm{ng} \mathrm{L}^{-1}$ range highlighting concern regarding the drug potential to non-target aquatic species.

Putting all biomarkers data together, confirm, once again, the reliability of this species for ecotoxicology assays, as well as the sediment compartment as an important target, especially regarding emergent contaminants such as anticancer pharmaceuticals.

\section{Acknowledgements}

This work was financed and supported by the Brazilian National Council for Scientific and Technological Development (CNPq), through the Science Without Borders Program (202360/2014-8). The authors would also like to acknowledge COST Action TD1407 - Network on technology-critical elements - from environmental processes to human health threats.

\section{References}

Aguirre-Martínez, G.V., DelValls, T.A., Martín-Díaz, M.L., 2013. Identification of biomarkers responsive to chronic exposure to pharmaceuticals in target tissues of Carcinus maenas. Mar. Environ. Res. 87-88, 1-11. http://dx.doi.org/10.1016/j.marenvres.2013. 02.011.

Aguirre-Martínez, G.V., DelValls, T.A., Martín-Díaz, M.L., 2016. General stress, detoxification pathways, neurotoxicity and genotoxicity evaluated in Ruditapes philippinarum exposed to human pharmaceuticals. Ecotoxicol. Environ. Saf. 124, 18-31. http://dx. doi.org/10.1016/j.ecoenv.2015.09.031.

Aljafari, A.A., 1995. Kinetics for the inhibition of acetylcholinesterase from human erythrocyte by cisplatin. Int. J. Biochem. Cell Biol. 27, 965-970. http://dx.doi.org/10.1016/ 1357-2725(95)00044-P.

American Society for Testing and Materials (ASTM), 2009. Standard guide for conducting sediment toxicity test with polychaetous annelids. vol. 11.06. ASTM Annual Book of Standards West Conshohocken, PA (Method E 1611-00) (Reapproved 2007).

Amiard-Triquet, C., 2009. Behavioral disturbances: the missing link between sub-organismal and supra-organismal responses to stress? Prospects based on aquatic research Hum. Ecol. Risk. Assess. 15, 87-110. http://dx.doi.org/10.1080/10807030802615543.

Amiard, J.-C., Amiard-Triquet, C., Barka, S., Pellerin, J., Rainbow, P.S., 2006. Metallothioneins in aquatic invertebrates: their role in metal detoxification and their use as biomarkers. Aquat. Toxicol. 76, 160-202. http://dx.doi.org/10.1016/j. aquatox.2005.08.015.
Aquilano, K., Baldelli, S., Ciriolo, M.R., 2014. Glutathione: new roles in redox signalling for an old antioxidant. Front. Pharmacol. 1-12 http://dx.doi.org/10.3389/fphar.2014. 001965 AUG.

Araujo, G.S., Moreira, L.B., Morais, R.D., Davanso, M.B., Garcia, T.F., Cruz, A.C.F., Abessa, D.M.S., 2013. Ecotoxicological assessment of sediments from an urban marine protected area (Xixova-Japui State Park, SP, Brazil). Mar. Pollut. Bull. 75, 62-68. http://dx.doi.org/10.1016/j.marpolbul.2013.08.005.

Arnesano, F., Natile, G., 2009. Mechanistic insight into the cellular uptake and processing of CisPt 30 years after its approval by FDA. Coord. Chem. Rev. 253, 2070-2081. http:// dx.doi.org/10.1016/j.ccr.2009.01.028.

Aureliano, M., Crans, D.C., 2009. Decavanadate and oxovanadates: oxometalates with many biological activities. J. Inorg. Biochem. 103, 536-546. http://dx.doi.org/10. 1016/j.jinorgbio.2008.11.010.

Aureliano, M., Henao, F., Tiago, T., Duarte, R.O., Moura, J.J.G., Baruah, B., Crans, D.C., 2008 Sarcoplasmic reticulum calcium ATPase is inhibited by organic vanadium coordination compounds: pyridine-2,6-dicarboxylatodioxovanadium(V), BMOV, and an amavadine analogue. Inorg. Chem. 2008 (47), 5677-5684. http://dx.doi.org/10 $1021 /$ ic702405d.

Bebianno, M.J., Langston, W.J., 1989. Quantification of metallothioneins in marine invertebrates using differential pulse polarography. Port. Electrochim. Acta 7, 59-64.

Besse, J.-P., Latour, J.-F., Garric, J., 2012. Anticancer drugs in surface waters: what can we say about the occurrence and environmental significance of cytotoxic, cytostatic and endocrine therapy drugs? Environ. Int. 39, 73-86. http://dx.doi.org/10.1016/j.envint 2011.10.002.

Bhagavan, N.V., 2002. Medical Biochemistry. Harcourt/Academic Press.

Bonnard, M., Romeo, M., Amiard-Triquet, C., 2009. Effects of Copper on the Burrowing Behavior of Estuarine and Coastal Invertebrates, the Polychaete Nereis diversicolor and the Bivalve Scrobicularia plana. Hum. Ecol. Risk. Assess. 15, 11-26. http://dx.doi.org/ $10.1080 / 10807030802614934$.

Bonnet, J.-L., Dusser, M., Bohatier, J., Laffosse, J., 2003. Cytotoxicity assessment of three therapeutic agents, cyclosporin-A, cisplatin and doxorubicin, with the ciliated protozoan Tetrahymena pyriformis. Res. Microbiol. 154, 375-385. http://dx.doi.org/10. 1016/S0923-2508(03)00085-8.

Booker, V., Halsall, C., Llewellyn, N., Johnson, A., Williams, R., 2014. Prioritising anticancer drugs for environmental monitoring and risk assessment purposes. Sci. Total Environ. 474, 159-170.

Boyd, W.A., Brewer, S.K., Williams, P.L., 2002. Altered behaviour of invertebrates living in polluted environments. In: Dell'Omo, G. (Ed.), Behavioural Ecotoxicology (John)

Bradford, M.M., 1976. A rapid and sensitive method for the quantitation of microgram quantities of protein utilizing the principle of protein-dye binding. Anal. Biochem. 72, 248-254.

Brezovsek, P., Elersek, T., Filipic, M., 2014. Toxicities of four anti-neoplastic drugs and their binary mixtures tested on the green alga Pseudokirchneriella subcapitata and the cyanobacterium Synechococcus leopoliensis. Water Res. 52, 168-177.

Buffet, P.-E., Tankoua, O.F., Pan, J.-F., Berhanu, D., Herrenknecht, C., Poirier, L., AmiardTriquet, C., Amiard, J.-C., Bérard, J.-B., Risso, C., Guibbolini, M., Roméo, M., Reip, P., Valsami-Jones, E., Mouneyrac, C., 2011. Behavioural and biochemical responses of two marine invertebrates Scrobicularia plana and Hediste diversicolor to copper oxide nanoparticles. Chemosphere 84, 166-174. http://dx.doi.org/10.1016/j. chemosphere.2011.02.003.

Buffet, P.-E., Amiard-Triquet, C., Dybowska, A., Risso-de Faverney, C., Guibbolini, M., Valsami-Jones, E., Mouneyrac, C., 2012. Fate of isotopically labeled zinc oxide nanoparticles in sediment and effects on two endobenthic species, the clam Scrobicularia plana and the ragworm Hediste diversicolor. Ecotoxicol. Environ. Saf. 84, 191-198. http://dx.doi.org/10.1016/j.ecoenv.2012.07.010.

Buffet, P., Pan, J., Poirier, L., Amiard-triquet, C., Amiard, J., Gaudin, P., Faverney, C.R. Guibbolini, M., Gilliland, D., Valsami-jones, E., Mouneyrac, C., 2013. Biochemical and behavioural responses of the endobenthic bivalve Scrobicularia plana to silver nanoparticles in seawater and microalgal food. Ecotoxicol. Environ. Saf. 89, 117-124.

Buffet, P.-E., Zalouk-Vergnoux, A., Châtel, A., Berthet, B., Métais, I., Perrein-Ettajani, H., Poirier, L., Luna-Acosta, A., Thomas-Guyon, H., Risso-de Faverney, C., Guibbolini, M., Gilliland, D., Valsami-Jones, E., Mouneyrac, C., 2014. A marine mesocosm study on the environmental fate of silver nanoparticles and toxicity effects on two endobenthic species: the ragworm Hediste diversicolor and the bivalve mollusc Scrobicularia plana. Sci. Total Environ. 470-471, 1151-1159. http://dx.doi.org/10. 1016/j.scitotenv.2013.10.114

Buruaem, L.M., Hortellani, M.A., Sarkis, J.E., Costa-lotufo, L.V., Abessa, D.M.S., 2012. Contamination of port zone sediments by metals from large marine ecosystems of Brazil. Mar. Pollut. Bull. 04. http://dx.doi.org/10.1016/j.marpolbul.2012.01.017.

Cajaraville, M.P., Bebianno, M.J., Blasco, J., Porte, C., Sarasquete, C., Viarengo, A., 2000. The use of biomarkers to assess the impact of pollution in coastal environments of the Iberian peninsula: a practical approach. Sci. Total Environ. 247, 295-311.

Calabrese, E.J., Baldwin, L., 2001. Hormesis: a generalizable and unifying hypothesis. Crit Rev. Toxicol. 31, 353-424. http://dx.doi.org/10.1080/20014091111730.

Calabrese, E.J., Blain, R.B., 2005. The occurrence of hormetic dose responses in the toxicological literature, the hormesis database: an overview. Toxicol. Appl. Pharmacol. 202 289-301. http://dx.doi.org/10.1016/j.yrtph.2011.06.003.

Cario, C., Malaval, L., Hernandez-Nicaise, M.L., 1995. Two distinct distribution patterns of sarcoplasmic reticulum in two functionally different giant smooth muscle cells of Beroe ovata. Cell Tissue Res. 282, 435-443.

Catalano, B., Moltedo, G., Martuccio, G., Gastaldi, L., Virno-Lamberti, C., Lauria, A., Ausili, A., 2012. Can Hediste diversicolor (Nereidae, Polychaete) be considered a good candidate in evaluating PAH contamination? A multimarker approach. Chemosphere 86 875-882. http://dx.doi.org/10.1016/j.chemosphere.2011.10.040.

Chu, G., 1994. Cellular Responses. J. Biol. Chem. 269, 787-790. 
Cobelo-García, A., Neira, P., Mil-homens, M., Caetano, M., 2011. Evaluation of the Contamination of Platinum in Estuarine and Coastal Sediments (Tagus Estuary and Prodelta Portugal). 62 pp. 646-650. http://dx.doi.org/10.1016/j.marpolbul.2010.12.018.

Colovic, M.B., Krstic, D.Z., Lazarevic-Pasti, T.D., Bondzic, A.M., Vasic, V.M., 2013. Acetylcholinesterase inhibitors: pharmacology and toxicology. Curr. Neuropharmacol. 11, 315-335.

Cong, Y., Banta, G.T., Selck, H., Berhanu, D., Valsami-jones, E., Forbes, V.E., 2011. Toxic effects and bioaccumulation of nano-, micron- and ionic-Ag in the polychaete Nereis diversicolor. Aquat. Toxicol. 105, 403-411. http://dx.doi.org/10.1016/j.aquatox.2011. 07.014 .

Cong, Y., Banta, G.T., Selck, H., Berhanu, D., Valsami-Jones, E., Forbes, V.E., 2014. Toxicity and bioaccumulation of sediment-associated silver nanoparticles in the estuarine polychaete, Nereis (Hediste) diversicolor. Aquat. Toxicol. 156, 106-115. http://dx.doi. org/10.1016/j.aquatox.2014.08.001.

Cossu, C., Doyotte, A., Babut, M., Exinger, A., Vasseur, P., 2000. Antioxidant biomarkers in freshwater bivalves, Unio tumidus, in response to different contamination profiles of aquatic sediments. Ecotoxicol. Environ. Saf. 121, 106-121. http://dx.doi.org/10. 1006/eesa.1999.1842.

Cravo, A., Pereira, C., Gomes, T., Cardoso, C., Serafim, A., Almeida, C., Rocha, T., Lopes, B. Company, R., Medeiros, A., Norberto, R., Pereira, R., Araújo, O., Bebianno, M.J., 2012. A multibiomarker approach in the clam Ruditapes decussatus to assess the impact of pollution in the Ria Formosa lagoon, South Coast of Portugal. Mar. Environ. Res. 75, 23-34. http://dx.doi.org/10.1016/j.marenvres.2011.09.012.

Curtis, L., Turner, A., Vyas, N., Sewell, G., 2010. Speciation and reactivity of cisplatin in river water and seawater. Environ. Sci. Technol. 44, 3345-3350. http://dx.doi.org/10.1021/ es903620z.

Damásio, J., Barceló, D., Brix, R., Postigo, C., Gros, M., Petrovic, M., Sabater, S., Guasch, H., de Alda, M.L., Barata, C., 2011. Are pharmaceuticals more harmful than other pollutants to aquatic invertebrate species: a hypothesis tested using multi-biomarker and multispecies responses in field collected and transplanted organisms. Chemosphere 85 1548-1554. http://dx.doi.org/10.1016/j.chemosphere.2011.07.058.

Dasari, S., Bernard Tchounwou, P., 2014. Cisplatin in cancer therapy: molecular mechanisms of action. Eur. J. Pharmacol. 740, 364-378. http://dx.doi.org/10.1016/j.ejphar. 2014.07.025.

De Boni, A., Cairns, W., Capodaglio, G., Cescon, P., Cozzi, G., Rauch, S., Hemond, H.F. Boutron, C., Barbante, C., 2007. On-line matrix separation for the determination of PGEs in sediments by ICP-MS. In: Morrison, G.M., Rauch, S. (Eds.), Highway and Urban Environment: Proceedings of the 8th Highway and Urban Environment Symposium. Springer, pp. 259-269.

Deans, A.J., West, S.C., 2011. DNA interstrand crosslink repair and cancer. Nat. Rev. Cancer 11, 467-480. http://dx.doi.org/10.1038/nrc3088.

Desoize, B., 2002. Cancer and metals and metal compounds: part II - cancer treatment. Crit Rev. Oncol. Hematol. 42, 213-215. http://dx doi.org/10.1016/S1040-8428(02)00039-2.

Doz, F., Roosen, N., Rosenblum, M.L., 1993. Metallothionein and anticancer agents: the role of metallothionein in cancer chemotherapy. J. Neuro-Oncol. 17, 123-129. http://dx.doi.org/10.1007/BF01050214.

Durou, C., Poirier, L., Amiard, J.-C., Budzinski, H., Gnassia-Barelli, M., Lemenach, K., Peluhet L., Mouneyrac, C., Roméo, M., Amiard-Triquet, C., 2007. Biomonitoring in a clean and a multi-contaminated estuary based on biomarkers and chemical analyses in the endobenthic worm Nereis diversicolor. Environ. Pollut. 148, 445-458. http://dx.doi. org/10.1016/j.envpol.2006.12.022.

Ellman, G.L., Courtney, K.D., Andres, V., Featherstone, R.M., 1961. A new and rapid colorimetrie determination of acetylcholinesterase activity. Biochem. Pharmacol. 7 $88-95$.

EMEA, 2006. Guideline on the Environmental Risk Assessment of Medical Products for Human Use. CPMP/SWP/4447/00. EMEA, London.

Erdelmeier, I., Gérard-Monnier, D., Yadan, J.C.. Chaudière, J., 1998. Reactions of N-methyl2-phenylindole with malondialdehyde and 4-hydroxyalkenals. Mechanistic aspects of the colorimetric assay of lipid peroxidation. Chem. Res. Toxicol. 11, 1184-1194. http://dx.doi.org/10.1021/tx970180z.

Fent, K., Weston, A.A., Caminada, D., 2006. Ecotoxicology of human pharmaceuticals. Aquat. Toxicol. 76, 122-159. http://dx.doi.org/10.1016/j.aquatox.2005.09.009.

Fraqueza, G., Batista de Carvalho, L.A.E., Marques, M.P., Maia, L., Ohlin, C.A., Casey, W.H., Aureliano, M., 2012a. Decavanadate, decaniobate, tungstate and molybdate interactions with sarcoplasmic reticulum Ca2 + -ATPase: quercetin prevents cysteine oxidation by vanadate but does not reverse ATPase inhibition. Dalton Trans. 41 12749-12758. http://dx.doi.org/10.1039/c2dt31688a.

Fraqueza, G., Ohlin, C.A., Casey, W.H., Aureliano, M., 2012b. Sarcoplasmic reticulum calcium ATPase interactions with decaniobate, decavanadate, vanadate, tungstate and molybdate. J. Inorg. Biochem. 107, 82-89. http://dx.doi.org/10.1016/j.jinorgbio.2011. 10.010

Fuertes, M.a., Alonso, C., Pérez, J.M., 2003. Biochemical modulation of cisplatin mechanisms of action: enhancement of antitumor activity and circumvention of drug resistance. Chem. Rev. 103, 645-662. http://dx.doi.org/10.1021/cr020010d.

Gagné, F., André, C., Blaise, C., 2008. The dual nature of metallothioneins in the metabolism of heavy metals and reactive oxygen species in aquatic organisms: implications of use as a biomarker of heavy-metal effects in field investigations. Biomark. Insights $1,23-33$.

Gajski, G., Geric, M., Zegura, B., Novak, M., Nunic, J., Bajrektarevic, D., GarajVrhovac, V., Filipic, M., 2015. Genotoxic potential of selected cytostatic drugs in human and zebrafish cells. Environ. Sci. Pollut. Res. Int. http://dx.doi.org/10.1007/s11356-0154592-6.

Garcia, A.M., Lennon, A.M., Hidalgo, C., 1975. Sarcoplasmic reticulum from barnacle muscle: composition and calcium uptake properties. FEBS Lett. 58, 344-348.

Gatti, L., Cassinelli, G., Zaffaroni, N., Lanzi, C., Perego, P., 2015. New mechanisms for old drugs: insights into DNA-unrelated effects of platinum compounds and drug resistance determinants. Drug Resist. Updat. 20, 1-11. http://dx.doi.org/10.1016/j. drup.2015.04.001.

Geracitano, L.A., Monserrat, J.M., Bianchini, A., 2004. Oxidative stress in Laeonereis acuta (Polychaeta, Nereididae): environmental and seasonal effects. Mar. Environ. Res. 58, 625-630. http://dx.doi.org/10.1016/j.marenvres.2004.03.053.

Geret, F., Serafim, A., Bebianno, M.J., 2003. Antioxidant enzyme activities, metallothioneins and lipid peroxidation as biomarkers in Ruditapes decussatus? Ecotoxicology 12, 417-426.

Gomes, T., Araújo, O., Pereira, R., Almeida, A.C., Cravo, A., Bebianno, M.J., 2013. Genotoxicity of copper oxide and silver nanoparticles in the mussel Mytilus galloprovincialis. Mar. Environ. Res. 84, 51-59.

Gomes, I.D.L., Lemos, M.F.L., Soares, A.M.V.M., Díez, S., Barata, C., Faria, M., 2014. Effects of Barcelona harbor sediments in biological responses of the polychaete Capitella teleta. Sci. Total Environ. 485-486, 545-553. http://dx.doi.org/10.1016/j.scitotenv.2014.03. 124

Gómez-Ruiz, S., Maksimovic-Ivanic, D., Mijatovic, S., Kaluderovic, G., 2012. On the discovery, biological effects, and use of cisplatin and metallocenes in anticancer chemotherapy. Bioinorg. Chem. Appl. http://dx.doi.org/10.1155/2012/140284 (14 pp.).

Gonzalez, V.M., Fuertes, M.A., Alonso, C., Perez, J.M., 2001. Is cisplatin-induced cell death always produced by apoptosis? Mol. Pharmacol. 59, 657-663.

Gonzalez-Rey, M., Bebianno, M.J., 2013. Does selective serotonin reuptake inhibitor (SSRI) fluoxetine affects mussel Mytilus galloprovincialis? Environ. Pollut. 173, 200-209. http://dx.doi.org/10.1016/j.envpol.2012.10.018.

Greenwald, R.A., 1985. Handbook of Methods for Oxygen Radical Research. CRC Press, Boca Raton, FL, USA

Gross, M.G., 1971. Carbon determination. In: Carver, R.E. (Ed.), Procedures in Sedimentary Petrology. Wiley-Interscience, New York, pp. 573-596.

Gusso-Choueri, P.K., Choueri, R.B., Santos, G.S., Araújo, G.S., Cruz, A.C.F., Stremel, T., Campos, S.X., Cestari, M.M., Ribeiro, C.A.O., Abessa, D.M.S., 2016. Assessing genotoxic effects in fish from a marine protected area influenced by former mining activities and other stressors. Mar. Pollut. Bull. http://dx.doi.org/10.1016/j.marpolbul.2016.01. 025

Habig, W.H., Pabst, M.J., Jakoby, W.B., 1974. Glutathione S-transferase: the first enzymatic step in mercapturic acid formation. J. Biol. Chem. 249, 7130-7139.

Hagrman, D., Dabrowiak, J.C., Goodisman, J., Souid, A., 2003. Kinetic Study of the Reaction of Cisplatin With Thiols Abstract. 31 pp. 916-923.

Hall, M.D., Telma, K.A., Chang, K.-E., Lee, T.D., Madigan, J.P., Lloyd, J.R., Goldlust, I.S., Hoeschele, J.D., Gottesman, M.M., 2014. Say no to DMSO: dimethylsulfoxide inactivates cisplatin, carboplatin and other platinum complexes. Cancer Res. 74 (14), 3913-3922. http://dx.doi.org/10.1158/0008-5472.CAN-14-0247 July 15.

Hann, S., Koellensperger, G., Stefa, Z., Stingeder, G., Fu, M., 2003. Application of HPLC-ICPMS to speciation of cisplatin and its degradation products in water containing different chloride concentrations and in human urine. J. Anal. At. Spectrom 1391-1395 http://dx.doi.org/10.1039/b309028k.

Hann, S., Stefánka, Z., Lenz, K., Stingeder, G., 2005. Novel separation method for highly sensitive speciation of cancerostatic platinum compounds by HPLC-ICP-MS. Anal. Bioanal. Chem. 381, 405-412. http://dx.doi.org/10.1007/s00216-004-2839-z.

Holzer, A.K., Manorek, G.H., Howell, S.B., 2006. Contribution of the major copper influx transporter CTR1 to the cellular accumulation of cisplatin, carboplatin, and oxaliplatin. Mol. Pharmacol. 70, 1390-1394. http://dx.doi.org/10.1124/mol.106. 022624.

Huang, Y., Li, L., 2013. DNA crosslinking damage and cancer - a tale of friend and foe. Transl. Cancer Res. 2, 144-154. http://dx.doi.org/10.1038/nature13314.A.

Hurst, R., Bao, Y., Jemth, P., Mannervik, B., Williamson, G., 1998. Phospholipid hydroperoxide glutathione peroxidase activity of human glutathione transferases. Biochem. J. 332, 97-100

Huska, D., Fabrik, I., Baloun, J., Adam, V., Masarik, M., Hubalek, J., Vasku, A., Trnkova, L. Horna, A., Zeman, L., Kizek, R., 2009. Study of interactions between metallothionein and cisplatin by using differential pulse voltammetry Brdicka's reaction and quartz crystal microbalance. Sensors 9, 1355-1369. http://dx.doi.org/10.3390/s90301355.

Jamieson, E., Lippard, S., 1999. Structure, recognition, and processing of cisplatin - DNA adducts. Chem. Rev. 99, 2467-2498. http://dx.doi.org/10.1021/cr980421n.

Johnson, A.C., Jürgens, M.D., Williams, R.J., Kümmerer, K., Kortenkamp, A., Sumpter, J.P., 2008. Do cytotoxic chemotherapy drugs discharged into rivers pose a risk to the environment and human health? An overview and UK case study. J. Hydrol. 348, 167-175. http://dx.doi.org/10.1016/j.jhydrol.2007.09.054

Kalman, J., Palais, F., Amiard, J.C., Mouneyrac, C., Muntz, A., Blasco, J., Riba, I., AmiardTriquet, C., 2009. Assessment of the health status of populations of the ragworm Nereis diversicolor using biomarkers at different levels of biological organisation. Mar. Ecol. Prog. Ser. 393, 55-67. http://dx.doi.org/10.3354/meps08239.

Karasawa, T., Steyger, P.S., 2015. An integrated view of cisplatin-induced nephrotoxicity and ototoxicity. Toxicol. Lett. 237, 219-227.

Kovacs, R., Bakos, K., Urbanyi, B., Kovesi, J., Gazsi, G., Csepeli, A., Appl, A.J., Bencsik, D., Csenki, Z., Horvath, A., 2015. Acute and sub-chronic toxicity of four cytostatic drugs in zebrafish. Environ. Sci. Pollut. Res. Int. http://dx.doi.org/10.1007/s11356-015-5036-z.

Kümmerer, K., Helmers, E., Hubner, P., Mascart, G., Milandri, M., Reinthaler, F., Zwakenberg, M., 1999. European hospitals as a source for platinum in the environment in comparison with other sources. Sci. Total Environ. 225, 155-165. http://dx. doi.org/10.1016/S0048-9697(98)00341-6.

Landeira-Fernandez, A.M., 2001. $\mathrm{Ca}^{2+}$ transport bythe sarcoplasmic reticulum $\mathrm{Ca}^{2+}$. ATPase in sea cucumber (Ludwigothurea grisea) muscle. J. Exp. Biol. 204, 909-921.

Lantzsch, H., Gebel, T., 1997. Genotoxicity of selected metal compounds in the SOS chromotest. Mutat. Res. Genet. Toxicol. Environ. Mutagen. 389, 191-197. http://dx. doi.org/10.1016/S1383-5718(96)00146-5.

Lawrence, R.A., Burk, R.F., 1976. Glutathione peroxidase activity in selenium-deficient rat liver. Biochem. Biophys. Res. Commun. 71, 952-958. 
Lenz, K., Hann, S., Koellensperger, G., Stefanka, Z., Stingeder, G., Weissenbacher, N. Mahnik, S.N., Fuerhacker, M., 2005. Presence of cancerostatic platinum compounds in hospital wastewater and possible elimination by adsorption to activated sludge. Sci. Total Environ. 345, 141-152. http://dx.doi.org/10.1016/j.scitotenv.2004.11.007.

Lenz, K., Koellensperger, G., Hann, S., Weissenbacher, N., Mahnik, S.N., Fuerhacker, M. 2007a. Fate of cancerostatic platinum compounds in biological wastewater treatment of hospital effluents. Chemosphere 69, 1765-1774. http://dx.doi.org/10.1016/j. chemosphere.2007.05.062.

Lenz, K., Mahnik, S.N., Weissenbacher, N., Mader, R.M., Krenn, P., Hann, S., Koellensperger, G., Uhl, M., Knasmüller, S., Ferk, F., Bursch, W., Fuerhacker, M., 2007b. Monitoring, removal and risk assessment of cytostatic drugs in hospital wastewater. Water Sci. Technol. 56, 141-149. http://dx.doi.org/10.2166/wst.2007.828.

Lewis, C., Galloway, T., 2008. Genotoxic damage in polychaetes: a study of species and cell-type sensitivities. Mutat. Res. Genet. Toxicol. Environ. Mutagen. 654, 69-75. http://dx.doi.org/10.1016/j.mrgentox.2008.05.008.

Liu, X., Zhang, J., Yin, J., Duan, H., Wu, Y., Shao, B., 2010. Analysis of hormone antagonists in clinical and municipal wastewater by isotopic dilution liquid chromatography tandem mass spectrometry. Anal. Bioanal. Chem. 396, 2977-2985. http://dx.doi.org/10. 1007/s00216-010-3531-0.

Maranho, L.A., Baena-nogueras, R.M., Lara-martín, P.A., Delvalls, T.A., 2014. Bioavailability, oxidative stress, neurotoxicity and genotoxicity of pharmaceuticals bound to marine sediments. The use of the polychaete Hediste diversicolor as bioindicator species. Environ. Res. 134, 353-365.

Maranho, L.A., André, C., DelValls, T.A., Gagné, F., Martín-Díaz, M.L., 2015. Toxicological evaluation of sediment samples spiked with human pharmaceutical products: energy status and neuroendocrine effects in marine polychaetes Hediste diversicolor. Ecotoxicol. Environ. Saf. 118, 27-36. http://dx.doi.org/10.1016/j.ecoenv.2015.04.010.

McCord, J.M., Fridovich, I., 1969. Superoxide dismutase: an enzymic function for erythrocuprein (hemocuprein). J. Biol. Chem. 244, 6049-6055.

Mcquillan, J.S., Kille, P., Powell, K., Galloway, T.S., 2014. The regulation of copper stress response genes in the polychaete Nereis diversicolor during prolonged extreme copper contamination. Environ. Sci. Technol. 48, 13085-13092.

Merk, O., Speit, G., 1999. Detection of crosslinks with the comet assay in relationship to genotoxicity and cytotoxicity. Environ. Mol. Mutagen. 33, 167-172. http://dx.doi. org/10.1002/(SICI)1098-2280(1999)33:2<167::AID-EM9>3.0.CO;2-D.

Milan, M., Pauletto, M., Patarnello, T., Bargelloni, L., Marin, M.G., Matozzo, V., 2013. Gene transcription and biomarker responses in the clam Ruditapes philippinarum after exposure to ibuprofen. Aquat. Toxicol. 126, 17-29. http://dx.doi.org/10.1016/j.aquatox. 2012.10.007.

Moreno-González, R., Rodriguez-mozaz, S., Gros, M., Barceló, D., León, V.M., 2015. Seasonal distribution of pharmaceuticals in marine water and sediment from a mediterranean coastal lagoon (SE Spain). Environ. Res. 138, 326-344.

Munari, M., Marin, M.G., Matozzo, V., 2014. Effects of the antidepressant fluoxetine on the immune parameters and acetylcholinesterase activity of the clam Venerupis philippinarum. Mar. Environ. Res. 94, 32-37. http://dx.doi.org/10.1016/j.marenvres. 2013.11.007.

Noll, D.M., Mason, T.M., Miller, P.S., 2006. Formation and repair of interstrand cross-links in DNA. Chem. Rev. 106, 277-301. http://dx.doi.org/10.1016/j.micinf.2011.07.011. Innate.

Nowosielska, A., Calmann, M.A., Zdraveski, Z., Essigmann, J.M., Marinus, M.G., 2004. Spontaneous and cisplatin-induced recombination in Escherichia coli. DNA Repair 3, 719-728. http://dx.doi.org/10.1016/j.dnarep.2004.02.009.

Parrella, A., Kundi, M., Lavorgna, M., Criscuolo, E., Russo, C., Isidori, M., 2014. Toxicity of exposure to binary mixtures of four anti-neoplastic drugs in Daphnia magna and Ceriodaphnia dubia. Aquat. Toxicol. 157, 41-46.

Parrella, A., Lavorgna, M., Criscuolo, E., Russo, C., Isidori, M., 2015. Eco-genotoxicity of six anticancer drugs using comet assay in daphnids. J. Hazard. Mater. 286, 573-580.

Payne, J.F., Mathieu, A., Melvin, W., Fancey, L.L., 1996. Acetylcholinesterase, an old biomarker with a new future? Field trials in association with two urban rivers and a paper mill in Newfoundland. Mar. Pollut. Bull. 32, 225-231. http://dx.doi.org/10. 1016/0025-326X(95)00112-Z.

Penner, N.W., Prakash, C., 2010. Drug Metabolzing Enzymes and Biotransformation Reactions. Wiley, New York, p. 2010.

Pérez, E., Blasco, J., Solé, M., 2004. Biomarker responses to pollution in two invertebrate species: Scrobicularia plana and Nereis diversicolor from the Cádiz bay (SW Spain). Mar. Environ. Res. 58, 275-279. http://dx.doi.org/10.1016/j.marenvres.2004.03.071.

Poirier, L., 2006. A Suitable Model for the Biomonitoring of Trace Metal Bioavailabilities in Estuarine Sediments: The Annelid Polychaete Nereis diversicolor. http://dx.doi.org/ 10.1017/S0025315406012872.

Prabhu, K.S., Reddy, P.V., Jones, E.C., Liken, A.D., Reddy, C.C., 2004. Characterization of a class alpha glutathione-S-transferase with glutathione peroxidase activity in human liver microsomes. Arch. Biochem. Biophys. 424, 72-80. http://dx.doi.org/10.1016/j. abb.2004.02.002.

Pratt, C., Lottermoser, B.G., 2007. Mobilisation of traffic-derived trace metals from road corridors into coastal stream and estuarine sediments, Cairns, northern Australia. Environ. Geol. 52, 437-448. http://dx.doi.org/10.1007/s00254-006-0471-2.
Prichard, H.M., Jackson, M.T., Sampson, J., 2008. Dispersal and accumulation of Pt, Pd and Rh derived from a roundabout in Sheffield (UK): From stream to tidal estuary. Sci. Total Environ. 401, 90-99. http://dx.doi.org/10.1016/j.scitotenv.2008.03.037.

Reedijk, J., 1999. Why does cisplatin reach guanine-N7 with competing s-donor ligands available in the cell? Chem. Rev. 99, 2499-2510. http://dx.doi.org/10.1021/cr980422f.

Rodrigues, S.K., Abessa, D.M.S., Machado, E.C., 2013. Geochemical and ecotoxicological assessment for estuarine surface sediments from Southern Brazil. Mar. Environ. Res. 91, 68-79. http://dx.doi.org/10.1016/j.marenvres.2013.02.005.

Royse, C.F., 1970. An Introduction to Sediment Analysis. Arizona State University, Tempe, AZ

Siddik, Z.H., 2003. Cisplatin: mode of cytotoxic action and molecular basis of resistance. Oncogene 22, 7265-7279. http://dx.doi.org/10.1038/sj.onc.1206933.

Simpson, S.L., Batley, G.E., Chariton, A.A., Stauber, J.L., King, C.K., Chapman, J.C., Hyne, R.V. Gale, S.A., Roach, A.C., Maher, W.A., 2005. Handbook for Sediment Quality Assessment. SCIRO, Bangor, NSW, Australia.

Singh, N.P., McCoy, M.T., Tice, R.R., Schneider, E.L., 1988. A simple technique for quantitation of low levels of DNA damage in individual cells. Exp. Cell Res. 175 184-191.

Slater, T.F., 1984. Free-radical mechanisms in tissue injury. Biochem. J. 222, 1-15.

Smith, D.J., Jaggi, M., Zhang, W., Galich, A., Du, C., Sterrett, S.P., Smith, L.M., Balaji, K.C. 2006. Metallothioneins and resistance to cisplatin and radiation in prostate cancer Urology 67, 1341-1347. http://dx.doi.org/10.1016/j.urology.2005.12.032.

Solé, M., Kopecka-Pilarczyk, J., Blasco, J., 2009. Pollution biomarkers in two estuarine invertebrates, Nereis diversicolor and Scrobicularia plana, from a marsh ecosystem in SW Spain. Environ. Int. 35, 523-531. http://dx.doi.org/10.1016/j.envint. 2008.09.013.

Supalkova, V., Beklova, M., Baloun, J., Singer, C., Sures, B., Adam, V., Huska, D., Pikula, J., Rauscherova, L., Havel, L., Zehnalek, J., Kizek, R., 2008. Affecting of aquatic vascular plant Lemna minor by cisplatin revealed by voltammetry. Bioelectrochemistry 72 , 59-65. http://dx.doi.org/10.1016/j.bioelechem.2007.11.012.

Suspiro, A., Prista, J., 2011. Biomarkers of occupational exposure do anticancer agents: a mini review. Toxicol. Lett. 207, 42-52. http://dx.doi.org/10.1016/j.toxlet.2011.08.022.

Tadini-Buoninsegni, F., Bartolommei, G., Moncelli, M.R., Inesi, G., Galliani, A., Sinisi, M., Losacco, M., Natile, G., Arnesano, F., 2014. Translocation of platinum anticancer drugs by human copper ATPases ATP7A and ATP7B. Angew. Chem. Int. Ed. 53 1297-1301. http://dx.doi.org/10.1002/anie.201307718.

Thain, J.E., Bifield, S., 2001. Biological effects of contaminants: sediment bioassay using the polychaete Arenicola marina. ICES Techniques in Marine Environmental Sciences. 29 17 pp.

Thit, A., Dybowska, A., Købler, C., Kennaway, G., Selck, H., 2015. Influence of copper oxide nanoparticle shape on bioaccumulation, cellular internalization and effects in the estuarine sediment-dwelling polychaete, Nereis diversicolor. Mar. Environ. Res. 111, 1-10. http://dx.doi.org/10.1016/j.marenvres.2015.06.009.

Trombini, C., Fonseca, T.G., Morais, M., Rocha, T.L., Blasco, J., Bebianno, M.J., 2016. Toxic effects of cisplatin cytostatic drug in mussel Mytillus galloprovincialis. Mar. Environ. Res. $119,12-21$.

Tuit, C.B., Ravizza, G.E., 2000. Anthropogenic platinum and palladium in the sediments of Environ. Sci. Technol. 34, 927-932.

Turner, A., Mascorda, L., 2015. Particle - water interactions of platinum-based anticancer drugs in river water and estuarine water. Chemosphere 119, 415-422.

Uozumi, J., Litterst, C.L., 1985. The effect of cispatin on renal ATPase activity in vivo and in vitro. Cancer Chemother. Pharmacol. 15, 93-96.

Van den Berg, R., Van den Berg, H., Haenen, G.R.M.M., Bast, A., 2005. Biomarkers for evaluating antioxidant effects. In: Suhr, Y.-J., Packer, L. (Eds.), Oxidative Stress, Inflamation and Health. CRC Press, Boca Raton, pp. 471-499.

Vermorken, J.B., Van der Vijgh, W.J.F., Klein, I., Gall, H.E., Van Groeningen, C.J., Hart, G.A.M., Pinedo, H.M., 1986. Pharmacokinetics of free and total platinum species after rapid and prolonged infusions of cisplatin. Clin. Pharmacol Ther. 39, 136-144.

Viarengo, A., Canesi, L., Pertica, M., Poli, G., Moore, M.N., Orunesu, M., 1990. Heavy metal effects on lipid peroxidation in the tissues of Mytillus galloprovincialis lam. Comp. Biochem. Physiol. 97C, 37-42.

Viarengo, A., Lowe, D., Bolognesi, C., Fabbri, E., Koehler, A., 2007. The use of biomarkers in biomonitoring: a 2-tier approach assessing the level of pollutant-induced stress syndrome in sentinel organisms. Comp. Biochem. Physiol. C 146, 281-300. http://dx.doi. org/10.1016/j.cbpc.2007.04.011.

Vyas, N., Turner, A., Sewell, G., 2014. Platinum-based anticancer drugs in waste waters of a major UK hospital and predicted concentrations in recipient surface waters. Sci. Total Environ. 493, 324-329.

Won, E.-J., Raisuddin, S., Shin, K.-H., 2008. Evaluation of induction of metallothionein-like proteins (MTLPs) in the polychaetes for biomonitoring of heavy metal pollution in marine sediments. Mar. Pollut. Bull. 57, 544-551. http://dx.doi.org/10.1016/j. marpolbul.2008.02.025.

Zounková, R., Odráska, P., Dolezalová, L., Hilscherová, K., Marsálek, B., Bláha, L., 2007. Ecotoxicity and genotoxicity assessment of cytostatic pharmaceuticals. Environ. Toxicol. Chem. 26, 2208-2214. http://dx.doi.org/10.1897/07-137R.1. 